\section{InII)et}

1.2021

Silvia Algaba Ros

Universidad de Málaga

\title{
El control de la renta en el arrendamiento de vivienda
}

\begin{abstract}
Sumario
$-$

Los poderes públicos deben promover las condiciones necesarias para que los ciudadanos disfruten de una vivienda digna y asequible, dictando las normas adecuadas para conseguirlo. Por ello se hace necesario introducir un control la renta de aquellos contratos de arrendamiento de vivienda que se celebran en territorios donde la cuantía fijada es inasumible para amplios sectores de la sociedad. El derecho de propiedad no se vería afectado por esta limitación de la autonomía de la voluntad, pues el contenido esencial de la propiedad se configura conforme a su función social.

La reciente publicación en Cataluña, de la Ley 11/2020, de 18 de septiembre, de medidas urgentes en materia de contención de rentas en los contratos de arrendamiento de vivienda, ha abierto un camino que anuncia los cambios normativos que sería necesario incorporar en la Ley de Arrendamientos Urbanos para hacer efectivo el derecho a la vivienda.
\end{abstract}

\begin{abstract}
Public authorities must promote the conditions necessary for citizens to enjoy decent and affordable housing. They must establish the appropriate rules to achieve this, including rent control in area where prices are unbearable for large sections of society. Ownership right would not be affected by this limitation because the essential content of property is configured in accordance with its social function.
\end{abstract}

The recent publication Catalonia Law 11/2020, of 18 September, on urgent measures for contain rents in housing leases, has opened up a regulatory path that announces the changes that should be incorporated.

Title: Price control on the rental housing

Palabras clave: Arrendamiento de vivienda, control de la renta, derecho a una vivienda digna y adecuada, renta inicial, actualizaciones de la renta

Keywords: Housing leasing, rent control, right to decent and adequate housing, initial rent income, rent increases

DOI: $10.31009 /$ InDret.2021.i1.02 


\section{InDret}

1.2021

Recepción

$17 / 11 / 2020$

Aceptación

28/12/2020

Î́ndice

\section{Notas previas}

2. Cuestiones relevantes para el análisis

2.1. Derecho de propiedad versus derecho a una vivienda

2.2. La limitación de la renta y su relación con el mercado del alquiler de vivienda

2.3. Sobre la necesidad de tener presente las circunstancias socioeconómicas del arrendador/arrendatario

3. El control de la renta en el contrato de arrendamiento de vivienda, un tema de ayer y de hoy.

4. La regulación de la renta: un retrato actual

4.1. Controles de la renta de primera generación: la renta de partida

4.1. Sobre la actualización de la renta.

4.3. La Ley del Parlament de Catalunya de medidas urgentes en materia de contención de rentas en los contratos de arrendamiento de vivienda

5. Hacia una futura regulación del control de la renta en la LAU

6. Bibliografía

Este trabajo se publica con una licencia Creative Commons Reconocimiento-No Comercial 4.0 Internacional @( 9 (i) 


\section{Notas previas*}

La vivienda, según la Real Academia Española, es "el lugar cerrado y cubierto construido para ser habitado por personas". Pero la vivienda es mucho más, se trata de un bien esencial que favorece el desarrollo personal y social de los ciudadanos, lo que evidencia su especial consideración por el ordenamiento jurídico y los poderes del estado. Justificadamente se relaciona con el libre desarrollo de la personalidad, dignidad e intimidad, es decir, es un marco imprescindible para el desenvolvimiento de derechos fundamentales.

En el actual contexto, la vivienda y el acceso al "espacio" donde ésta se desarrolla, pueden ser analizados desde planos jurídicos muy diversos. Unos tienen naturaleza de derecho público como los que abordan las subvenciones a la vivienda, el fomento de construcción de viviendas sociales, planificaciones urbanísticas, incentivos fiscales... Otros se encuentran enmarcados en el derecho privado proyectándose en ámbitos diversos como son la regulación de las Sociedades Anónimas Cotizadas de Inversión Inmobiliaria (SOCIMI), los préstamos garantizados con hipotecas concertados para favorecer su adquisición, formas de tenencia de bienes inmuebles al margen de la propiedad, contrato de arrendamiento... Sin intención de minorar la trascendencia de los numerosos planos afectados que en numerosas ocasiones entran en intersección, en este trabajo nos vamos a centrar en el precio (renta) ${ }^{1}$ del contrato de arrendamiento de vivienda y en concreto en su contención. No se abordará la problemática de los contratos de arrendamientos de viviendas de protección oficial.

El precio del contrato de arrendamiento es muy sensible a cualquier cambio económico-social. Hasta febrero de 2020, el problema socio-económico y jurídico que planteaba el precio en los arrendamientos de vivienda se centraba en la extraordinaria subida que las rentas estaban experimentando haciendo difícil el acceso a la vivienda a los sectores más vulnerables de la sociedad $^{2}$. En este contexto, se destacaban como causas que provocaban una subida de las rentas, la inexistencia de control legal, la escasez de viviendas en alquiler, la gentrificación, la proliferación de los alquileres turísticos... Pero la sociedad está en continuo cambio y el derecho es permeable a los mismos. A partir de marzo de 2020 se ha producido una alarma sanitaria, que se ha proyectado en muchos ámbitos y también en el contrato de arrendamiento de vivienda aunque desde una óptica diferente a la que se planteaba con anterioridad. Se desconoce en el momento de esta publicación si la situación previa a febrero de 2020 resurgirá en el futuro, pero lo que parece notorio es que el contexto socioeconómico generado por la situación de pandemia de la COVID -19 está planteando problemas socioeconómicos que afectarán, entre otros ámbitos,

\footnotetext{
* Silvia Algaba Ros, salgaba@uma.es. Este trabajo se realiza en el marco del Proyecto de Investigación "Retos del siglo XXI. Propuesta de modernización del Derecho de Obligaciones. Los contratos de tracto sucesivo". UMA 18- FERDERJA-233.

${ }^{1}$ Conforme a los arts. 1543 y 1555.1 Cc la renta es el precio cierto que el arrendatario se compromete a pagar al arrendador en el contrato de arrendamiento.

2 Como se desprende del Preámbulo de la Ley 18/2007, del derecho a la vivienda (BOE n ${ }^{\circ} 50$ de 27.02.2008; última modificación por Decreto-ley 1/2020, de 21 de enero (BOE $n^{\circ} 71$ de 17 de marzo de 2020) referido a la Comunidad Autónoma de Cataluña pero trasladable a otras Comunidades en ese momento histórico "La oferta de viviendas en alquiler es manifiestamente insuficiente o no es competitiva, dado que las rentas son elevadas... En consecuencia, cada vez más los sectores sociales sensibles, tales como los jóvenes, las personas de la tercera edad, los inmigrantes y las personas en situación de riesgo, sufren situaciones de exclusión del derecho a la vivienda”.
} 
también a la accesibilidad a los arrendamientos de vivienda. Ello ha determinado la publicación del RDL 11/2020, 31 de marzo, por el que se adoptan medidas urgentes complementarias en el ámbito social y económico para hacer frente al COVID-19 (BOE núm. 91, de 1.04.2020) (en adelante, RDL $11 / 2020)^{3}$. La citada norma en la que se incide entre otras cuestiones en el precio del arrendamiento de vivienda abordando la moratoria de la deuda arrendaticia para las personas arrendatarias de vivienda habitual en situación de vulnerabilidad económica a causa del COVID19, ha sido reformada, entre otros, por el RDL 30/2020, de 29 de septiembre, de medidas sociales en defensa del empleo (BOE $n^{\circ} .259$, de 30.09.2020) (en adelante, RDL 30/2020) en el que amplía hasta el 31 de marzo de 2021 el plazo para solicitar la moratoria o condonación parcial de la deuda, cuando el arrendador sea gran tenedor o entidad pública ${ }^{4}$.

El análisis del control de la renta del arrendamiento de vivienda, que vamos a abordar en este trabajo está enmarcado en un horizonte a alcanzar por la Agenda 2030 para el desarrollo Sostenible, aprobado en 2015 por los Estados Miembros de Naciones Unidas que es plan de acción a favor de las personas, el planeta y la prosperidad. En dicha Agenda se señala como OBJETIVO 11.1 "De aquí a 2030, asegurar el acceso de todas las personas a viviendas y servicios básicos adecuados, seguros y asequibles y mejorar los barrios marginales”, y resultará difícil asegurar el acceso a la vivienda sin abordar de forma eficaz e integral los numerosos ámbitos a los que anteriormente nos hemos referido y en concreto aquél que va a ocupar este trabajo: el precio en el contrato de arrendamiento de vivienda ${ }^{5}$. No se puede obviar que a fecha de esta publicación el salario mínimo interprofesional es de 950 euros al mes ${ }^{6}$ y el precio medio de las rentas supera de forma abrumadora el $40 \%$ de dicho salario en las ciudades especialmente tensionadas ${ }^{7}$. Esta complicada situación que ha determinado la publicación en Cataluña de la LEY 11/2020, de 18 de septiembre, de medidas urgentes en materia de contención de rentas en

\footnotetext{
3 Obsérvese que otras legislaciones de países de nuestro entorno han regulado medidas que afectan a la renta del contrato de alquiler para atender a la situación excepcional ocasionada por el COVID-19. Es el caso de Alemania donde como indica LeHMANN (2020, pp. 4 y ss.) se publicó una norma que permitía al arrendatario suspender el pago de la renta durante un período determinado si el cumplimiento fuera imposible por causa en el COVID y para evitar poner en peligro el sustento del arrendatario y de su familia. Pero esta excepción al pago no se podía oponer "si éste crea un riesgo para el sustento del acreedor o de su familia o para la continuación de su empresa. De esta formulación se puede desprender que, en caso de que peligren por igual ambos intereses, es decir, el interés del deudor y el del acreedor, prevalecen los de este último. Sin embargo, en estas circunstancias la ley concede al deudor el derecho de extinguir el contrato para el futuro".

4 Debe tenerse presente que el RDL 11/2020, también se ha reformado por Real Decreto Ley 37/2020, de 22 de diciembre de medidas urgentes para hacer frente a las situaciones de vulnerabilidad social y económica en el ámbito de la vivienda y en materia de transportes (BOE n.334, de 23.12.2020) al introducir el art. 1 bis para dar cobertura a situaciones en las que los procedimientos de desahucio y lanzamiento afecten a personas económicamente vulnerables sin alternativa habitacional, incluso en las causas penales. Este art. 1 bis, ha vuelto a ser reformado por el Real Decreto Ley 1/2021, de 19 de enero, de protección de los consumidores y usuarios frente a situaciones de vulnerabilidad social y económica (BOE n. 17, de 20.01.2021).
}

5 Vid. la Nueva Agenda Urbana que se aprobó en la Conferencia de las Naciones Unidas sobre la Vivienda y el Desarrollo Urbano Sostenible (Hábitat III) celebrada en Quito, Ecuador, el 20 de octubre de 2016 fue refrendada por la Asamblea General de las Naciones Unidas el 23 de diciembre de 2016.

6 Vid. Real Decreto 231/2020, de 4 de febrero, por el que se fija el salario mínimo interprofesional para 2020 (BOE $\mathrm{n}^{\mathrm{o}} 31$, de 05.02.2020)

7 Vid. el Índice del alquiler de vivienda publicado por el Ministerio de Transporte, Movilidad y Agenda Urbana, https://www.mitma.gob.es/vivienda/alquiler/indice-alquiler 
los contratos de arrendamiento de vivienda y de modificación de la Ley 18/2007, de la Ley 24/2015 y de la Ley 4/2016, relativas a la protección del derecho a la vivienda (DOGC $\mathrm{n}^{\circ} 8229$, de 21.09.2020, BOE $n^{\circ} 258$, de 29.09.2020) (en adelante, Ley 11/2020 CAT), también está planteando la necesidad de una futura reforma de la Ley 29/1994, de 24 de noviembre (BOE nº282, de 25.11.1994) (en adelante, LAU) que garantice el acceso de los ciudadanos a una vivienda asequible.

Tras la aprobación de la Resolución del Parlamento Europeo de 21 de enero de 2021sobre el acceso a una vivienda digna y asequible para todos (en adelante, Resolución 21.01.2021), la reforma de la LAU se hace más necesaria para garantizar el acceso de los ciudadanos a una vivienda asequible.

\section{Cuestiones relevantes para el análisis}

La preocupación del legislador por el contrato de arrendamiento de vivienda ha sido una constante en nuestra historia jurídica. Como señala AviLÉS GARCíA (2014, p.1) “No es exagerado afirmar que el legislador tiene la «obligación de medios reforzada» de adaptar las leyes que afectan al derecho a la vivienda a la cambiante realidad social". Sin embargo esa necesaria adaptación no termina de producirse en la LAU.

Es notorio que en España el contrato de alquiler, no es el régimen de tenencia más utilizado por la población para ubicar su vivienda ${ }^{8}$. Existe una preferencia por la vivienda en propiedad que se puede poner en relación con tres elementos señalados por NASARRE AZNAR (2020, pp. 52 y ss): a) la propiedad es un sistema de tenencia más rentable desde una perspectiva económica, b) existe una preferencia "oficial" por la propiedad que se manifiesta en las "diferencias clave entre la normativa que ampara en España el mercado de vivienda en propiedad y el de vivienda en alquiler”, y, c) la debilidad del estado social favorece la propiedad ${ }^{9}$.

8 Vid. estos efectos las estadísticas sobre vivienda de Eurostat. Mayo 2020. https:/ec.europa.eu/eurostat/statistics-explained/pdfscache/14813.pdf. Afirma NASARRE AzNAR (2020, p.59) que "en los últimos doce años de boom inmobiliario (1995-2007), en una sociedad en que los propietarios han obtenido importantes beneficios (ej. revalorizaciones constantes de sus viviendas) a un coste crediticio muy bajo, en las que el acceso a la vivienda en alquiler no ha sido promovido y ha resultado más caro que comprar con hipoteca (hasta 2007 y de nuevo desde 2012 hasta hoy) y donde el Estado Social es relativamente débil (y de cuyos gestores poco esperamos), es racional que exista una gran preferencia por la vivienda en propiedad".

9 Textualmente sostiene NASARRE AZNAR que: “En cuanto al primer elemento, KeMENY intenta explicar cuál es la relación que se establece entre los patrones de tipo de tenencia de la vivienda con el provecho económico que se puede sacar de ella. En una sociedad capitalista es lógico que el sistema de tenencia mayoritario sea el que es más rentable económicamente hablando, lo que lo explica con la creciente importancia... de las entidades financieras que se aprovechan de la tenencia en propiedad a través de la financiación hipotecaria; también se aprovechan las profesiones jurídicas implicadas en la transacción inmobiliaria (...), así como también la industria inmobiliaria (...), dado que cada vez que se efectúa una compra-venta, participan. Nada de ello sucede con la vivienda en alquiler.... b) En cuanto al segundo de los elementos, a la preferencia "oficial" por la propiedad... diferencias clave entre la normativa que ampara en España el mercado de vivienda en propiedad y el de vivienda en alquiler... c) Y, en cuanto al tercer elemento, la debilidad del Estado Social, a KeMENY también le intrigó cómo países con un alto estándar de vida, como los Países Bajos, Alemania, Dinamarca y Suiza, tenían bajas tasas de vivienda en propiedad, cuestionando la relación entre vivienda en propiedad y altos estándares de vida”. 
No obstante el relativo peso del arrendamiento de vivienda como forma de acceso a una vivienda, no priva de fuerza a la necesidad de reflexionar sobre su regulación con el fin de favorecer que los ciudadanos en el marco de la LAU puedan acceder a una vivienda digna y adecuada, que les pueda resultar accesible sin tener que soportar unas rentas excesivamente elevadas.

Desde la citada perspectiva, resulta llamativo observar cómo desde diversos enfoques entre los que se encuentra el jurídico, se plantean reticencias y opiniones contrarias a la limitación del precio $^{10}$ cuando es manifiesto cómo se expondrá en otro apartado de este trabajo, que en nuestra historia jurídica se han acogido regulaciones que limitaban el precio de los contratos de arrendamientos y además se admite generalmente sin demasiada polémica la limitación del tiempo en los citados contratos. Además ya tenemos la Ley 11/2020 CAT que regula la contención de la renta en Cataluña, siguiendo el camino ya transitado de forma bastante generalizada en sistemas jurídicos de derecho comparado.

Pero, por qué se plantean tantos inconvenientes a incorporar controles de la renta en la LAU. Para abordar este interrogante reflexionaremos sobre diversas cuestiones que están en la base de la cuestión planteada.

\subsection{Derecho de propiedad versus derecho a una vivienda}

Propiedad y vivienda son dos pilares que gravitan independientes e interrelacionados, integrándose y contraponiéndose.

Nos recuerda RODRíGUEZ RAMOS (2015, pp.202) que "vivienda y propiedad no son hermanas siamesas...No podemos confundir el derecho de propiedad con el objeto del mismo. Primero, porque no es necesario ser dueño para disfrutar legítimamente de la tierra y la vivienda. Y segundo, porque ser dueño sólo nos proporciona la máxima garantía jurídica frente a su desposesión, pero siempre y cuando la propiedad se encuentre libre de cargas hipotecarias de naturaleza abusiva" ${ }^{11}$. Además la vivienda como nos señala NASARRE AZNAR (2020, p. 52) "es un fenómeno muy complejo, que se debate permanentemente entre su consideración como activo financiero y fundamento para el mercado hipotecario (art. 2 LMH) y ser el centro por excelencia para desarrollar derechos fundamentales, como el de la libertad -

10 CABRILlo Rodriguez (2019, p. 4) defiende que un control de la renta puede ser perjudicial: "El gran error de los controles de rentas radica en presuponer que la oferta de viviendas en alquiler es estable y no va a cambiar como consecuencia de una reforma legal que perjudica de forma evidente a los propietarios de las viviendas”.

11 Plantea asimismo RoDRIGUEz RAMOS (2015, pp. 202-203) que "no debemos poner el enfoque garantizador de los derechos humanos en el derecho privado y excluyente de propiedad, forzando su justificación según el objeto sobre el que recaiga, sino en el derecho universal e incluyente de residencia. En este caso concreto, a una vivienda digna. El cambio de mirada coloca en el núcleo del derecho a la posesión. No cabe duda que la protección posesoria es más débil que la derivada del dominio, y que no es igual según se trate de una posesión justa (posee quien debe poseer) o injusta (posee quien no debe poseer). E incluso dentro de esta última, no merece idéntico trato jurídico el poseedor de buena fe (cree equivocadamente que tiene derecho a poseer) que el poseedor de mala fe (sabe a ciencia cierta que no tiene derecho a poseer). En todos estos casos, incluida la posesión injusta de mala fe, el poseedor es protegido por las legislaciones civiles por el mero hecho de poseer. Creemos de justicia que los derechos humanos de residencia deben tutelar a los poseedores justos e incluso a los injustos de buena fe de una vivienda en su calidad de bien jurídico”. 
art. $16 \mathrm{CE} ; . . .-$, el de la intimidad - art. $18 \mathrm{CE} ; . . .-$ o el del libre desarrollo de la personalidad art. 10.1 CE; ...-, además de concretar y hacer tangible el derecho a la vivienda (art. $47 \mathrm{CE}$ ) “. También merece la protección que le brinda el art. 39 CE en tanto que los poderes públicos deben asegurar la protección social, económica y jurídica de la familia.

Los ciudadanos en cuanto pueden ser arrendatarios tienen derecho a que los poderes públicos arbitren los mecanismos para que puedan acceder a una vivienda digna y adecuada. Por otra parte, los ciudadanos que son propietarios de un bien inmueble tienen derecho a disfrutar de su propiedad, materialmente ubicando en ella su vivienda, pues los propietarios también son partícipes de la protección que proyecta del derecho a la vivienda digna y adecuada. Por tanto, la relación entre derecho de propiedad y derecho a la vivienda no debe ser analizada necesariamente en términos de conflicto pues el derecho de propiedad también se beneficia de la protección que le brinda el derecho a una vivienda digna y adecuada, cuando en la propiedad se ubica la vivienda del titular ${ }^{12}$.

La relación conflictual entre el derecho de propiedad y el derecho a la vivienda, se produce cuando el derecho de propiedad recae sobre un bien inmueble destinado a vivienda y se procede a celebrar un contrato de arrendamiento. La renta del arrendamiento es un fruto civil de la propiedad y es aquí donde puede producirse una tensión entre el derecho de propiedad (disfrute) con el derecho a una vivienda digna y adecuada. Precisamente en este punto cabria plantearse si el derecho a la vivienda podría justificar una limitación del disfrute del derecho a la propiedad. Nos recuerda Molina RoIG (2018, p. 342) que "históricamente se ha tratado de buscar un equilibrio entre los intereses de los arrendadores, que se centran en obtener beneficios de la explotación de viviendas en régimen de alquiler, y lo intereses de los arrendatarios, que precisan una renta asequible de acuerdo con sus ingresos y normas que proporcionen cierta estabilidad y seguridad jurídica”. Y en la búsqueda del equilibrio hay que valorar la naturaleza de los dos polos del mismo: propiedad y vivienda.

Para el estudio de la citada cuestión, el texto constitucional ofrece un marco relevante de análisis. El derecho de propiedad y derecho a un vivienda digna y adecuada se regulan en el Título Primero de la CE, lo que determina que por aplicación del art. 86.1 CE ambos derechos no sean susceptibles de regulación por Decreto ley. Pero a salvo de la citada semejanza, emergen significativas diferencias en el texto constitucional.

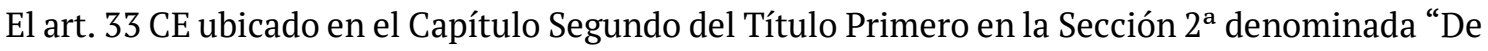
los derechos y deberes de los ciudadanos" reconoce el derecho a la propiedad privada y concreta que la función social de este derecho delimitará su contenido. Posteriormente el propio texto constitucional en el Capítulo Tercero del Título I denominado "De los principios rectores de la política social y económica" en su art. 47 CE declara "Todos los españoles tienen derecho a disfrutar de una vivienda digna y adecuada. Los poderes públicos promoverán las condiciones necesarias y establecerán las normas pertinentes para hacer efectivo este derecho...”.

\footnotetext{
12 Esta protección del derecho a una vivienda digna y adecuada del propietario de la misma se materializa en normas de protección como se constata en la regulación de la moratoria de la deuda hipotecaria, de los art. 7 y 8 del RDL 8/2020, de 17 de marzo, de medidas urgentes extraordinarias para hacer frente al impacto

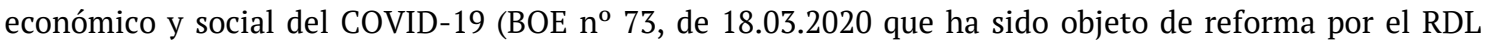
11/2020).
} 
La concreta denominación de los preceptos en el Título I de la Constitución nos pone en alerta de que la propiedad se regula como un "derecho" pues así se nombra en la Sección donde se ubica el precepto y en el texto del art. 33 CE. El "derecho a disfrutar de una vivienda digna y adecuada" se menciona como tal "derecho" en el art. 47 CE pero se regula en el Capítulo III del Título I como un principio rector de la política social y económica ${ }^{13}$. Esta diferente denominación y localización se proyecta en otra singularidad, el diferente tratamiento que merece la regulación de los citados derechos/principios en el art. 53 CE. Señala en el apartado $1^{\text {a }}$ que el derecho de propiedad se tutelará por la vía del art. 161.1.a) y sólo por ley podrá regularse respetando en todo caso su contenido esencial. Prevé el art. 53.3 CE que los principios reconocidos en el capítulo de tercero (derecho a disfrutar de una vivienda digna y adecuada) sólo podrán ser alegados ante la Jurisdicción ordinaria de acuerdo con lo que dispongan las leyes que los desarrollen e informará la legislación positiva, la práctica judicial y la actuación de los poderes públicos. Por tanto, frente al derecho de propiedad, el derecho a disfrutar de una vivienda digna y adecuada no tiene reserva de ley, ni existe especial protección de su contenido esencial y no se encuentra protegido por el art. 161.1.a); además es rubricado como un principio rector de política social. Pero dichas singularidades no desdibujan que ambos son derechos reconocidos constitucionalmente aunque no queda claro si existe una relación jerarquizada entre ellos.

Son numerosas las definiciones que se han dado del "Derecho" y son muchos los que han proclamado su naturaleza contingente y sometida a las veleidades del distinto perfil ideológico de los legisladores. La concreta configuración de cada Parlamento determinará una distinta caracterización de las normativas. No es el momento ni el lugar de profundizar sobre qué sea el "Derecho" pero sí debemos precisar que no todos los derechos tienen la misma trascendencia pues los "derechos humanos" son un prius al propio Derecho al abarcar las facetas más esenciales de lo humano. Son un prius porque el reconocimiento no les viene de su toma en consideración por el Derecho, ya que son regulados precisamente por su cualidad previa de "humanos". Los derechos humanos no atienden a fronteras, ni a sistemas políticos pues deben ser siempre respetados, tienen una vocación de universalidad. Como nos recuerda PECES-BARBA (2019, pp. 17 y ss.) "Para defender el universalismo hay que elevarse desde las pretensiones morales concretas que respaldan cada derecho, a la moralidad básica y genérica que respalda al conjunto de los derechos: es decir la moralidad de la dignidad humana y de los grandes valores de libertad, de igualdad, de fraternidad o solidaridad y de seguridad. Es la universalidad de la vocación moral única de los seres humanos, que deben ser considerados como fines y no como medios y que deben tener unas condiciones de vida social que les permita elegir libremente sus planes de vida (su moralidad privada)".

En relación a la valoración del derecho de propiedad y del derecho a disfrutar de una vivienda digna y adecuada, constituyen un elemento relevante para su análisis los tratados internacionales válidamente celebrados y publicados oficialmente, pues conforme al principio de prevalencia las normas contenidas en dichos Tratados prevalecerán "sobre cualquier otra

13 Obsérvese que en la Constitución en el Título I se distinguen entre derechos fundamentales y libertades públicas (Capítulo I, Sección $1^{\mathrm{a}}$ ), derechos y deberes de los ciudadanos (Capítulo 1, Sección 2a) donde se ubica el art. 33 CE, y finalmente los principios rectores de la política social y económica (Capítulo Tercero) que acoge el art. $47 \mathrm{CE}$. 
norma del ordenamiento interno en caso de conflicto con ellas, salvo las normas de rango constitucional” ${ }^{14}$.

Constituye un hito relevante la Declaración Universal de Derechos Humanos (BOE nº243, de 10.10.1979) donde se reconoce el derecho a la propiedad (art. 17) y el derecho a un nivel de vida adecuado de toda persona y su familia que le asegure, entre otros, la vivienda (art.25.1) ${ }^{15}$. Esta singular redacción ha planteado dudas sobre si el derecho a la vivienda es un derecho humano, frente al "derecho de la propiedad" que es considerado sin contradicción como un derecho humano al ser reconocido como tal el derecho de "toda persona a la propiedad individual y colectiva”. No obstante, las dudas planteadas quedan disipadas si se pone el acento en otros textos jurídicos internacionales. Así en el Pacto Internacional de Derechos Económicos y Sociales adoptado y abierto a la firma, ratificación y adhesión por la Asamblea General en su resolución 2200 A (XXI), de 16 de diciembre de 1966 (BOE núm.103, de 30.04.1977) en el art. 11 establece que "Los Estados Partes en el presente Pacto reconocen el derecho de toda persona a un nivel de vida adecuado para sí y su familia, incluso alimentación, vestido y vivienda adecuados, y a una mejora continua de las condiciones de existencia”. El Comité de Derechos Económicos, Sociales y Culturales, en la Observación General núm. 4 (1991) en relación al Derecho a una vivienda adecuada (art. 11.1) señala en el párrafo 8.c que es posible identificar algunos aspectos del citado derecho que deben ser tenidos en cuenta en cualquier contexto determinado cual es que" De conformidad con el principio de la posibilidad de costear la vivienda, se debería proteger por medios adecuados a los inquilinos contra niveles o aumentos desproporcionados de los alquileres”. Además en la citada Observación General, el Comité señaló que todas las personas” deberían gozar de cierto grado de seguridad de tenencia que les garantice una protección legal contra el desalojo forzoso, el hostigamiento u otras amenazas". Con ello se constata el reconocimiento como derecho humano, del derecho a la vivienda y se concreta entre otras cuestiones en la necesidad de proteger al ser humano frente a niveles o aumentos excesivos de las rentas de los arrendamientos de vivienda ${ }^{16}$.

14 Vid. art. 31 de la ley 25/2014, de 27 de noviembre de Tratados y otros Acuerdos Internacionales (BOE $n^{\circ}$ 288, de 28.11. 2014).

15 Artículo 25.1 de la Declaración Universal de Derechos Humanos: “Toda persona tiene derecho a un nivel de vida adecuado que le asegure, así como a su familia, la salud y el bienestar, y en especial la alimentación, el vestido, la vivienda, la asistencia médica y los servicios sociales necesarios; tiene asimismo derecho a los seguros en caso de desempleo, enfermedad, invalidez, viudez, vejez y otros casos de pérdida de sus medios de subsistencia por circunstancias independientes de su voluntad".

16 Otros textos también se han referido a la condición de derecho humano, del derecho a la vivienda. Nos recuerda GARCÍA HERRERA (2016) que “A partir de dicho reconocimiento, el derecho a una vivienda adecuada (o alguno de sus elementos, como la protección del hogar y la privacidad) se ha consagrado en otros Tratados Internacionales de los derechos humanos; así: Convenio de Ginebra relativo a la Protección debida a las Personas Civiles en Tiempo de Guerra de 1949 (arts. 49, 53, 85 y 134), Convención sobre el Estatuto de los Refugiados de 1951 ( art. 21 ), Convenio número 110 de la Organización Internacional del Trabajo (OIT) relativo a las Condiciones de Empleo de los Trabajadores de las Plantaciones de 1958 (art. 88.1), Recomendación número 15 de la Organización Internacional del Trabajo (OIT) sobre la Vivienda de los Trabajadores de 1961 (Observaciones Generales números 4 y 7), Convenio número 117 de 1962 de la Organización Internacional del Trabajo sobre Política Social (normas y objetivos básicos) (art. 5.2), Convención Internacional sobre la eliminación de todas las formas de discriminación racial de 1965 (art. 5, e, iii), Pacto Internacional de los Derechos Civiles y Políticos de 1966 ( art. 17 ), Convenio Internacional sobre la eliminación de todas las formas de discriminación contra la mujer de 1979 (arts. 14.2 h), Convenio número 161 de la Organización Internacional del Trabajo (OIT) relativo a los Servicios de Salud en el Trabajo de 1985 (art. 5 b), Convenio sobre los Derechos del Niño de 1989 ( arts. 16.1 y 27.3 ), Convenio número 
En Europa, el Convenio para la Protección de los derechos Humanos y Libertades Fundamentales, de 04 de noviembre de 1950, ratificado por Instrumento de 26 de septiembre de 1979 (BOE núm. 243, de 10.10.1979) (en adelante, CEDH) no menciona expresamente ni el derecho de propiedad ni el derecho a la vivienda. En el Protocolo adicional al Convenio para la protección de los derechos humanos y las libertades fundamentales de 20 de marzo de 1952, Instrumento de 2 de noviembre de 1979 (BOE núm. 11, de 12.01.1991) se incluyó el derecho a la propiedad ${ }^{17}$, pero no el derecho a la vivienda. En el ámbito del derecho comunitario, la Carta Europea de Derechos Fundamentales (DOUE ${ }^{\circ}$. 83, de 30.03.2010) menciona el derecho de propiedad aunque no regula expresamente el derecho a disfrutar de una vivienda digna y adecuada. No obstante, pese a la falta de reconocimiento formal del derecho a la vivienda como derecho humano, existe un reconocimiento material que ha sido constatado en la STJUE, $3^{\text {a }}$, de 10.09.2014 (TJCE 312, MP: C. TOADER) donde se señala "en el Derecho de la Unión, el derecho a la vivienda es un derecho fundamental garantizado por el artículo 7 de la Carta...” ${ }^{18}$. Además la Resolución 21.02.2021 ha dado un paso adelante en este camino al instar a los estados de la unión a tomar las medidas adecuadas para favorecer el derecho a una vivienda digna y asequible que caracteriza como un "derecho humano"19.

Con el breve repaso realizado, se pone de manifiesto que no existen motivos para jerarquizar entre el derecho de propiedad y el derecho a una vivienda digna y adecuada pues ambos tienen la misma consideración de derechos humanos. Entonces será preciso recurrir a otras vías para examinar la relación existente entre ambos derechos ${ }^{20}$.

169 de 1989 de la Organización Internacional del Trabajo sobre Pueblos Indígenas y Tribales ( arts. 14 , 16 y 17 ), Convención Internacional sobre la protección de los derechos de todos los trabajadores migratorios y sus familiares de 1990 (art. 43.1 d), Convención de las Naciones Unidas sobre los derechos de las personas con discapacidad adoptada por la Asamblea General en su sesión número 61 en diciembre de 2006 (arts. 9 y 28) y Declaración sobre los Derechos de los Pueblos Indígenas de 2007... (arts. 10, 21.1, 23, 26, 27, 28 y 32)”.

17 En concreto señala el citado Protocolo Adicional en su "Artículo 1. Protección de la propiedad. Toda persona física o moral tiene derecho al respeto de sus bienes. Nadie podrá ser privado de su propiedad más que por causa de utilidad pública y en las condiciones previstas por la ley y los principios generales del Derecho Internacional. Las disposiciones precedentes se entienden sin perjuicio del derecho que poseen los Estados de poner en vigor las leyes que juzguen necesarias para la reglamentación del uso de los bienes de acuerdo con el interés general o para garantizar el pago de los impuestos u otras contribuciones o de las multas". Obsérvese que en la redacción original no aparecía como entrada a este artículo la denominación de "Protección de la propiedad".

${ }^{18}$ En concreto se relaciona con el art. 7 de la Carta de los Derechos Fundamentales de la Unión Europea que establece: "Respeto de la vida privada y familiar. Toda persona tiene derecho al respeto de su vida privada y familiar, de su domicilio y de sus comunicaciones". Obsérvese que en la Carta Social Europea revisada, hecha en Estrasburgo el 3 de mayo de 1996 señala expresamente en su art. 31 "Derecho a la vivienda. Para garantizar el ejercicio efectivo del derecho a la vivienda, las Partes se comprometen a adoptar medidas destinadas: 1. a favorecer el acceso a la vivienda de una calidad suficiente; 2 . a prevenir y paliar la situación de carencia de hogar con vistas a eliminar progresivamente dicha situación; 3. a hacer asequible el precio de las viviendas a las personas que no dispongan de recursos suficientes".

${ }_{19}^{19}$ Así se desprende del punto 45 de la Resolución 21.01.2021 donde se manifiesta que "Observa con preocupación el aumento de la financiarización del mercado de la vivienda, en particular en las ciudades, al tratar los inversores la vivienda como un activo negociable y no como un derecho humano".

20 Resulta llamativo comprobar que existen pronunciamientos jurisprudenciales rotundos que señalan que el derecho a la vivienda es un derecho humano, en aquellos casos en los que dicho derecho a la vivienda no entra en colisión con del derecho a la propiedad. Así en el ámbito del derecho de familia encontramos sentencias como STS de 19 de enero de 2017, (ROJ 113/2017, MP: Jose Antonio SEIJAS QUINTANA) donde se 
Una primera mirada nos lleva a reiterar que el derecho de propiedad no se encuentra enfrentado al derecho a la vivienda, pues ambos se complementan como se observa cuando se protege a los propietarios de viviendas frente a las ejecuciones hipotecarias. No obstante, estos derechos entran en colisión, como ya hemos señalado, en aquellos casos en los que se contraponen intereses del disfrute del "derecho de propiedad" de un inmueble destinado a vivienda y el "derecho a disfrutar de una vivienda digna y adecuada" del arrendatario que tiene la posesión legítima de dicho bien. Nos encontramos entonces con la "posible colisión" del derecho de propiedad y el derecho a una vivienda digna y adecuada.

Este choque de intereses entre ambos derechos puede ser valorado desde el propio texto constitucional, teniendo presente que el derecho de propiedad reconocido en el art. 33 CE no es incondicional pues "la función social de dicho derecho delimitará su contenido". Y esta "función social" encuentra desarrollo en el propio texto Constitucional. En el art. $47 \mathrm{CE}$ al establecer que "todos los españoles tienen derecho a disfrutar de una vivienda digna y adecuada. Los poderes públicos promoverán las condiciones necesarias y establecerán las normas pertinentes para hacer efectivo este derecho". En el art. 128 CE establece que "toda la riqueza del país, en sus distintas formas, y sea cual fuere su titularidad, está subordinada al interés general” y en el art. $40 \mathrm{CE}$ que encomienda "a los poderes públicos que promuevan las condiciones favorables para el progreso social y económico y para una distribución de la renta más equitativa“. Y es que el derecho de propiedad según señala el texto Constitucional se encuentra delimitado por su función social, pero dicha función social trasciende de ser un mero límite. Como señala la Sentencia del Tribunal Constitucional de Pleno de 26 de marzo de 1987 (BOE 14.04.1987) ${ }^{21}$ la "fijación del contenido esencial de la propiedad privada no puede hacerse desde la exclusiva consideración subjetiva del derecho o de los intereses individuales que a éste subyacen, sino que debe incluir igualmente la necesaria referencia a la función social, entendida no como mero límite externo a su definición o a su ejercicio, sino como parte integrante del derecho mismo. Utilidad individual y función social definen, por tanto inescindiblemente el contenido del derecho de propiedad sobre cada categoría o tipo de bienes» ${ }^{22}$.

Por tanto, el derecho de propiedad incluye en su contenido esencial ${ }^{23}$ tanto la utilidad y disfrute individual como su función social. En este contexto, la fijación de una limitación de los frutos de la propiedad de una finca en la que se fija una vivienda para favorecer el derecho a disfrutar de una vivienda digna y adecuada, no desdibuja el contenido esencial del derecho de propiedad pues

declara que "no se ignora que la vivienda constituye uno de los derechos humanos fundamentales en cuanto garantiza a su titular el derecho al desarrollo e la personalidad y le asegura una existencia digna”.

${ }^{21}$ En esta Sentencia se resuelve el recurso de inconstitucionalidad promovido contra algunos artículos de la Ley del Parlamento de Andalucía 8/1984 de 3 de julio de Reforma Agraria.

22 Así lo pone de manifiesto en la Exposición de Motivos del Decreto-Ley 6/2013, de 9 de abril, de medidas para asegurar el cumplimiento de la Función Social de la Vivienda (BOJA núm. 69, de 11.04.2013) que expresivamente señala "La función social de la vivienda, en suma, no es un límite externo a su definición o a su ejercicio, sino una parte integrante del derecho mismo. Utilidad individual y función social, por tanto, componen de forma inseparable el contenido del derecho de propiedad”.

${ }^{23}$ Sobre el contenido esencial de un derecho subjetivo vid la Sentencia del Tribunal Constitucional de Pleno 11/1981, de 8 de abril (BOE de 25.04.1981) en relación al recurso de inconstitucionalidad presentado frente a varios preceptos del Real Decreto Ley 17/1977, de 4 de marzo, regulador del derecho de huelga y de los conflictos colectivos de trabajo. 
la función social del mismo lo impide ${ }^{24}$. Desde este punto de vista, se podría dar un paso más en la interpretación del "derecho a la vivienda" siguiendo el faro proyectado desde el ordenamiento jurídico alemán. En este país no solo el arrendador sino también el arrendatario está protegido por el derecho de propiedad, pues como nos recuerdan BEATE GSELl, MARKUS ARTZ, ARROYO Amayuelas ( 2017, p. 6) "el Tribunal Constitucional Federal... atribuye carácter de propiedad al derecho de posesión del inquilino sobre la vivienda arrendada...no sólo el arrendador sino también el arrendatario disfrutan de protección constitucional según el art. 14 de la Constitución, que garantiza la protección de la propiedad privada. Si esta protección constitucional fuera ignorada por el legislador o por los tribunales civiles competentes en litigios de naturaleza arrendaticia, el arrendatario podría defenderse con un recurso de inconstitucionalidad" 25 .

En cualquier caso, si el derecho a una vivienda digna se configura como un derecho humano que es reconocido por Tratados Internacionales y que además forma parte del propio contenido esencial de la propiedad, no debería plantear problema alguno una regulación que limite el precio de la renta en el marco de la protección del derecho a la vivienda.

La vivienda, que según nos recuerda NASARRE AZNAR (2020, p. 46) "es el único bien que concentra la cualidad de derecho humano y de importante activo financiero", y ello es el origen de una tensión que no debería ser tal pues su carácter de derecho humano siempre debe imperar sobre su consideración de activo financiero. El derecho a la vivienda debe primar y no ser objeto de valoraciones económicas que determinen su regulación. Lo importante no es la eficiencia económica del mercado sino favorecer el efectivo derecho a la vivienda de todos los ciudadanos.

\subsection{La limitación de la renta y su relación con el mercado del alquiler de vivienda}

El mercado del alquiler de vivienda en España es débil ${ }^{26}$. Nos indica el Real Decreto 106/2018, de 9 de marzo, por el que se regula el Plan Estatal de Vivienda 2018-2021 (BOE núm. 61, de10.03.2018) en su Preámbulo que "En la actualidad, pese a observarse un gran dinamismo en

\footnotetext{
24 Desde una perspectiva diferente también favorece la admisión de controles a la renta, la Sentencia del tribunal Constitucional de Pleno de 17 de marzo de 1994 (BOE n. 89, de 14.04.1994). Bello JANEIRo (1994, p. 17) al comentar esta Sentencia señala que “... la prórroga obligatoria para el arrendador, y los preceptos que la establecen pueden implicar una limitación del derecho de propiedad en cuanto a su utilidad económica, sin que ello, en modo alguno, signifique que la tan repetida prórroga convierta en inexistente o puramente nominal el derecho de propiedad del arrendador puesto que "no puede considerarse una supresión del derecho sino, en todo caso, una afectación de su contenido que no lo hace desaparecer ni lo convierte en irreconocible" en tanto que "queda justificada en virtud de la función social que a la propiedad atribuye el artículo 33 de la Constitución”.

25 Continúan los autores citados que "También los tribunales civiles, y no solo el legislador, vigilan para que se cumpla debidamente la protección del derecho del arrendatario. De acuerdo con el BVerfG, eso quiere decir que al aplicar las normas sobre arrendamientos contenidas en el BGB, los tribunales están obligados a vigilar mediante la garantía de propiedad los límites impuestos [...] en la ley, basada en fundamentos constitucionales, como expresión de la ponderación de intereses, de tal manera que se entienda y que tenga en cuenta la protección de la propiedad de ambas partes y se eviten restricciones injustificadas." BEATE Gsell, Markus Artz, Arroyo Amayuelas ( 2017, pp. 6-7).

26 CABrillo Rodríguez (2019, p.2) nos indica que al articular la protección se debe evitar "reducir los incentivos tanto para construir nuevas viviendas destinadas al alquiler como para poner en el mercado muchas de las casas ya existentes”.
} 
la actividad de arrendamiento de vivienda y un significativo aumento del porcentaje de población que reside en alquiler, que ha alcanzado el 22,2 \% en España según datos de Eurostat, aún se encuentra alejado de la media de la Unión Europea, situada en el 30,8 \%”. Las razones de ello merecen comentarios muy variados y a veces contradictorios que nos llevan a plantearnos la cuestión alegada por numerosos operadores jurídicos de que la limitación de la renta en los contratos de arrendamiento desincentivaría la oferta en el mercado del alquiler de vivienda ${ }^{27}$, lo que en última instancia perjudicaría el derecho a la vivienda. Pero esta opinión merece una reflexión pausada de la cual quizás pueden extraerse conclusiones bien diferentes.

Es notorio que el contrato de arrendamiento de vivienda se caracteriza porque una de las partes se obliga a dar a la otra el uso de una vivienda por tiempo determinado y precio cierto (renta). "Tiempo" y "renta" son elementos identificadores del contrato 28 ; por ello no sólo la limitación de la renta, sino también del tiempo debería influir sobre la oferta. Pero basta con hacer un recorrido por la legislación que regula este contrato en el siglo XX y XXI para comprobar que pese a la trascendencia de ambos elementos, sólo el "tiempo" ha sido limitado de forma significativa en numerosas reformas (tres, cinco, siete años) sin que se hayan planteado problemas de incidencia sobre la oferta, problemas que sin embargo se mencionan cuando se propone un "control de la renta". Existe un diferente trato del "tiempo" y la "renta” que no está justificado.

Además merece destacarse que "tiempo" y "renta” afectan diversamente a las partes del contrato de arrendamiento influyendo no sólo en la oferta sino también en la demanda y por tanto afectando al mercado del arrendamiento de vivienda. Si atendemos a sus intereses personales, mientras a los arrendadores oferentes les favorece la falta de limitación de la autonomía de la voluntad sobre el tiempo, a los demandantes arrendatarios les beneficia que exista limitación. Se puede presumir que los ciudadanos demandarán más la utilización del contrato de arrendamiento para materializar su vivienda cuando puedan disponer con seguridad de mayor tiempo de ésta y que se ofertarán más propiedades en arrendamiento de vivienda cuando menos límites temporales tengan que soportar el arrendador. Por otro lado, si existe limitación en la renta existirá más demanda de arrendamiento, aunque se pueda entender que al provocar menos beneficios existirá menos oferta de arrendamiento. Pero "tiempo" y "renta" no pueden valorarse como compartimentos estancos pues se encuentran íntimamente relacionados, dado que la limitación de la autonomía de la voluntad de cada uno de ellos incidirá en el otro.

27 Se manifiesta contrario a fijar un precio tasado del arrendamiento FuENTES LOJO al afirmar que "Por lo que respecta a la regulación del precio de la renta, no soy partidario de regularlo, por los perniciosos efectos que puede producir en el mercado del alquiler de uso de vivienda, ya exiguo de por sí en estos momentos, tal como evidencia el fenómeno de la gentrificación que se está produciendo en algunos barrios de ciudades como Barcelona o Madrid. Conviene recordar que en el TRLAU 64 ya se establecían controles sobre el aumento de la renta y el mercado de alquiler se contrajo en España hasta solo el 18\% de la oferta de vivienda, agravando aún más las dificultades de acceso a la vivienda de la ciudadanía... No obstante, sí que soy partidario de establecer unas rentas de mercado orientativas en aquellos barrios de ciudades con mayor demanda, que vengan acompañadas de incentivos fiscales para los arrendadores que las respeten (ej: bonificaciones en el IBI, ayudas a la rehabilitación...)”. Vid. VALLEJO ROS Y SÁNCHEZ GARCÍA (2018, pp. 3 у 4$)$.

28 En la LAU en su art. 9 se establece un periodo mínimo de duración del contrato de cinco o siete años según nos encontremos ante un arrendador persona física o jurídica, alejándose de la respuesta dada en otros ordenamientos. En este sentido nos recuerda MOLINA ROIG (2019, p. 4) que “... la mayoría de los países europeos disponen de dos tipos de contratos de alquiler. El contrato de duración determinada para dar respuesta a los grupos de demanda temporal y transitoria y, el contrato de duración indefinida, para dar respuesta a las familias con proyectos de vida estables". 
El tema que tratamos admite además otra lectura que no puede ser obviada. Los componentes básicos del mercado del arrendamiento de vivienda, oferta y demanda, responden a dinámicas distintas. La oferta en una primera aproximación puede verse fomentada por la falta de limitación de la renta, pues el arrendador tendrá mayores expectativas de obtener cuantiosos frutos y ello le animará a ofrecer los bienes inmuebles de su propiedad en arrendamiento de vivienda. Pero a la larga la situación cambiará de perfil, pues si las subidas del alquiler son excesivas se desincentivaría la demanda. Así la falta de limitación de la renta puede provocar un incremento desmedido del precio del arrendamiento que lleve a sectores pudientes de la sociedad a apostar por otras instituciones para el acceso a una vivienda, huyendo de los contratos de arrendamientos. Además puede exponer a los sectores vulnerables a afrontar precios para los que no tienen capacidad económica lo que favorece los impagos de las rentas. Y todo ello tiene un fuerte coste que repercute en última instancia en la oferta desincentivándola y moviéndola a otros ámbitos del tráfico jurídico. Desde esta perspectiva no es extraño que en los últimos tiempos se hayan destinado numerosos inmuebles en un principio destinados a vivienda, a alojamientos turísticos con un grave coste social: disminución en las fincas ofrecidas para el arrendamiento de viviendas, aumentos de los arrendamientos de habitaciones de una vivienda, cambio en la configuración de los centros de las ciudades donde los "habitantes" son desplazados por turistas y disminución en la calidad de vida de aquellos vecinos que deben compartir los elementos comunes de su comunidad con clientes de alojamientos turísticos.... Llegados a este punto, aunque no vamos a referirnos a los alojamientos turísticos en este trabajo, no se puede obviar que estos arrendamientos si continúan con la proliferación que tenían antes de la pandemia, van a dibujar un mapa de las ciudades turísticas en las que la población residente se desplace de los centros de la ciudad y de algunos de sus barrios más apreciados, favoreciéndose en general la elevación de los precios y la reducción de los inmuebles ofrecidos para el alquiler de vivienda ${ }^{29}$.

Pero la situación es aún más compleja pues la evidente trascendencia de los citados elementos ("renta" y "tiempo") no puede llevarnos a pensar que son los únicos factores que determinan o no la demanda y oferta de los alquileres de vivienda, pues también inciden en su fomento el

\footnotetext{
29 Debe tenerse presente que los alquileres turísticos no se encuentran regulados en la LAU y que tras el Real Decreto-ley 7/2019, de 1 de marzo, de medidas urgentes en materia de vivienda y alquiler (BOE $n^{\circ} 55$, de 05.03.2019) se ha incrementado el control de las comunidades de vecinos de dichos arrendamientos, pues dicha comunidades pueden oponerse a que un piso tenga un uso turístico mediante acuerdo de tres quintas partes. También podrían admitir estos pisos turísticos pero incrementando en un 20 por ciento la cuota anual de la comunidad. Debe tenerse presente que estos acuerdos no tendrán efecto retroactivo y no se aplicarán a aquellas viviendas que ejerciesen esta actividad con anterioridad a entrar en vigor el citado Real Decreto ley. Obsérvese que recientemente en relación a los arrendamientos turísticos, se ha dictado la Sentencia del Tribunal de Justicia de la unión Europea (Gran Sala) de 22 de septiembre de 2020 (asuntos acumulados C-724/18 y C-727/18) en la que se resuelve una cuestión prejudicial planteada por el Tribunal de Casación de Francia sobre la necesidad de que exista una autorización administrativa previa antes de iniciar la actividad de "arrendamiento de inmuebles amueblados a clientes de paso que no fijan el domicilio en ellos, efectuado de forma reiterada y durante breves períodos de tiempo". La Sala tras declarar que es aplicable a estos arrendamientos la Directiva 2006/123/CE falla, que es lícito supeditar la actividad de dichos arrendamientos a autorizaciones previas pues “está justificada por una razón imperiosa de interés general contra la lucha contra la escasez de viviendas destinadas al arrendamiento y es proporcionada al objetivo perseguido.... A la vista de objetivos de diversidad social y en función de las características de los mercados locales de la vivienda y de la necesidad de no agravar la escasez de viviendas...” Desde luego en nuestro ordenamiento serían también interesantes incorporar esas autorizaciones administrativas previas para favorecer una gestión razonable de los alquileres turísticos.
} 
conjunto de derechos y obligaciones de que disponen las partes para satisfacer sus intereses. En este sentido, partiendo de Molina RoIG (2018, pp 740 y ss.) podemos observar que al arrendatario le conviene una regulación que le dé "estabilidad" y sea "flexible jurídicamente, de forma que se facilite al máximo su movilidad territorial y el pago de la renta cuando existan dificultades para ello". Desde la perspectiva del arrendador "es preciso otorgar garantías suficientes... para evitar o paliar el mal uso que el arrendatario pueda realizar..." y facilitar al arrendador la rápida recuperación de la vivienda arrendada a la finalización del contrato o ante el incumplimiento del arrendatario.

En virtud de lo expuesto, se observa que aunque una posible limitación de la renta puede afectar al mercado del alquiler sin embargo no es el único elemento que lo hace, ni es determinante ${ }^{30}$.

Tampoco cabe sostener que la limitación de la renta afectará negativamente al mercado del alquiler de vivienda, porque su falta de limitación le podría incidir en el mismo sentido. Por ello, la cuestión que planteamos no es si debemos o no regular el precio de la renta desde la perspectiva del fomento del mercado del alquiler. El tema a tratar es cómo se regula y controla el precio para conseguir que los ciudadanos puedan articular adecuadamente su derecho a la vivienda. Para ello además de medidas de derecho privado, sería preciso adoptar otras de naturaleza pública como pueden ser incentivos fiscales (reducción de IBI...), subvenciones (ayudas a la rehabilitación...) ${ }^{31}$ aunque en este trabajo solo se aborde la medida civil de control de la renta.

\subsection{Sobre la necesidad de tener presente las circunstancias socioeconómicas del arrendador/arrendatario}

La renta en los arrendamientos de vivienda tiene una significativa proyección socioeconómica que es diversa según nos situemos en la posición de los arrendadores o de los arrendatarios, por ello es conveniente analizar si una regulación de la limitación de la renta debe incidir en las características de cada uno de ellos.

Comenzando el análisis por los arrendatarios, observamos que éstos tienen perfiles diferentes. Pueden tratarse de ciudadanos solventes económicamente que precisan de una vivienda arrendada para vivir en ella por razones de movilidad laboral, por necesidad de cursar estudios fuera del lugar de residencia, por precisar una ubicación mientras adquieren un inmueble donde

30 Desde otro enfoque, López-Rodríguez y De Los Llanos MATEA (2020, p.8 ) señalan que en los últimos tiempos "Este aumento de los precios se asocia a una escasez relativa de la oferta de vivienda en alquiler, frente a un notable incremento de la demanda entre determinados colectivos, entre los que destacan los hogares con menor nivel de renta y los encabezados por adultos jóvenes, y se ha localizado fundamentalmente en las áreas geográficas donde tiende a concentrarse la actividad económica, como es el caso de las ciudades globales y sus distritos céntricos [Comisión Europea (2019)]. Entre los principales factores que podrían explicar este aumento de la demanda de alquiler, se encuentran el menor dinamismo de la rentas del trabajo (en especial, entre los jóvenes y los trabajadores con menor formación), los cambios en el mercado del crédito hipotecario después de la reciente crisis financiera internacional y la mayor concentración de la actividad económica y de los flujos migratorios en las principales ciudades dentro de cada país (superstar cities) [Matlack y Vigdor (2008), Myers y Pitkin (2009), Acemoglu y Autor (2011), Gyourko et al. (2013), Acolin et al. (2016), Whitehead et al. (2016), Myers et al. (2016), Autor et al. (2014) y Hornbeck y Moretti (2019)]. Este aumento de la demanda de alquiler habría sido, en general, mayor que el incremento de la oferta, relativamente rígida en el corto plazo, creando de este modo una escasez relativa de vivienda que habría ocasionado subidas significativas de los precios del alquiler”.

31 Vid. Vallejo Ros y Sánchez García (2018, p.1 y ss.) 
situar su vivienda definitiva... Pero abundan los arrendatarios cuya finalidad al contratar es establecer en dicho arrendamiento, su vivienda, su proyecto de vida... además dentro de éstos se encuentran sectores vulnerables como es la población jubilada que deben hacer frente a la renta con su pensión de jubilación, los jóvenes que se enfrentan a los arrendamientos con la exigua capacidad económica que les ofrecen sus primeros salarios, hogares con escaso nivel de renta...

También los arrendadores son diversos, pues mientras que nos encontramos con grandes tenedores que convierten la vivienda en un bien de mercado, un activo financiero con el que negociar y obtener rendimientos, también se encuentran "pequeños propietarios" que precisan para subsistir de las rentas que obtienen, convirtiéndose dichas rentas en su medio de vida. Un breve recorrido por la legislación vigente nos pone en alerta de que el legislador tiene presente esta diversidad. La LAU establece en su art. 9 una distinción entre arrendadores persona física y jurídica que se proyecta en la duración del contrato de arrendamiento de vivienda que éste tendrá una duración mínima en beneficio del arrendatario de cinco y siete años respectivamente. También en el citado precepto se establece la posibilidad de que el arrendador que sea persona física pueda recuperar la vivienda en los casos tasados una vez que transcurra el primer año del contrato, circunstancia que no se prevé para los supuestos en los que el arrendador sea persona jurídica y otra toma en consideración de la distinción se produce en relación al art. 14 LAU con respecto a la enajenación de la vivienda arrendada ${ }^{32}$.

La cualidad del arrendatario también es tenida en cuenta en la LAU. Así en relación a los derechos de subrogación en caso de muerte del arrendatario, el art. 16.4 establece para el caso de que el contrato se haya acordado por una fecha superior a cinco o siete años ( arrendador persona física y jurídica) que "no podrá pactarse esta renuncia al derecho de subrogación en caso de que las personas que puedan ejercitar tal derecho en virtud de lo dispuesto en el apartado 1 de este artículo se encuentren en situación de especial vulnerabilidad y afecte a menores de edad, personas con discapacidad o personas mayores de 65 años”. Pero sin duda es la Disposición transitoria segunda de la LAU que se refiere a los contratos de arrendamiento de vivienda celebrados con anterioridad al 9 de mayo de 1985, donde más se toma en consideración la cualidad del arrendatario pues pese a que en dicha disposición se establecía un sistema de actualización de las rentas de dichos contratos que en 1994 se encontraban congeladas, sin embargo también se regulaba que "no procederá la actualización de renta prevista en este apartado cuando la suma de los ingresos totales que perciba el arrendatario y las personas que con él convivan habitualmente en la vivienda arrendada, no excedan de" un concreto límite que sitúa a dichos arrendatarios en una situación de vulnerabilidad. Para estos casos, el apartado $8^{\text {a }}$ de la Disposición que se menciona establece que en "los supuestos en que no proceda la actualización, la renta que viniese abonando el inquilino, incrementada en las cantidades asimiladas a ella, podrá actualizarse anualmente a tenor de la variación experimentada por el Índice General de Precios al Consumo en los doce meses inmediatamente anteriores a la fecha de cada actualización”.

\footnotetext{
32 En concreto, se establece en el segundo párrafo del art. 14 LAU "Enajenación de la vivienda arrendada" que “...Si la duración pactada fuera superior a cinco años, o superior a siete años si el arrendador anterior fuese persona jurídica, el adquirente quedará subrogado por la totalidad de la duración pactada, salvo que concurran en él los requisitos del artículo 34 de la Ley Hipotecaria. En este caso, el adquirente sólo deberá soportar el arrendamiento durante el tiempo que reste para el transcurso del plazo de cinco años, o siete años en caso de persona jurídica, debiendo el enajenante indemnizar al arrendatario con una cantidad equivalente a una mensualidad de la renta en vigor por cada año del contrato que, excediendo del plazo citado de cinco años, o siete años si el arrendador anterior fuese persona jurídica...”
} 
Más recientemente el RDL 11/2020 al establecer un régimen especial para afrontar los efectos de la pandemia ha diferenciado entre el arrendador persona física (pequeño propietario) y, arrendador que sea empresa, entidad pública de vivienda o gran tenedor ("persona física y jurídica que sea titular de más de diez inmuebles urbanos, excluyendo garajes y trasteros, o una superficie construida de más de $1.500 \mathrm{~m}$ ”) ${ }^{33}$ estableciendo un sistema de protección diferente. No obstante debe tenerse presente que como señala la Exposición de Motivos del RDL 11/2020: “En España, en el 85\% de los arrendamientos de vivienda el propietario es una persona física, pequeño propietario". También el citado RDL contiene normas protectoras del arrendatario vulnerable, precisando en su art. 5.1 qué requisitos deberá cumplir para tener esta consideración.

El breve recorrido realizado por la normativa vigente, nos pone de manifiesto que en la regulación actual se tiene presente la distinta naturaleza de los arrendatarios y arrendadores para precisar la regulación aplicable. Por ello, no sería contrario al sistema en una futura regulación de la renta mantuviese la citada distinción pues si las circunstancias del arrendador y arrendatario son diversas, la protección que merecen también lo debe ser especialmente cuando se atiende a la regulación de la renta.

No se puede obviar que con la normas de control de renta, se trata de favorecer el acceso de los ciudadanos a una vivienda "asequible" y dicha asequibilidad en un estado social no puede desatender las concretas circunstancias económicas de las partes. Las normas de contención suponen una restricción a la obtención de beneficios que está justificada pues la vivienda no puede convertirse en un activo de ganancia económica desatendiendo que en ella se materializa un derecho humano. Ello exige que se atiendan las peculiaridades socioecónomicas de arrendadores y arrendatarios, gravando especialmente a los grandes tenedores que convierten la vivienda en un activo económico. Pero también ha sido criticada esta especial restricción a la obtención de beneficios por los grandes tenedores por los posibles resultados negativos respecto a los pequeños ahorradores que hubieran podido invertir sus ahorros en sociedades de gestión de rentas de alquiler ${ }^{34}$. No obstante, pese a ser cierto que puede perjudicarles, nuestro sistema

\footnotetext{
33 Esta distinción precisada en el RDL 11/2020 es trascendente, en relación a las siguientes materias: "suspensión del procedimiento de desahucio y de los lanzamientos para hogares vulnerables sin alternativa habitacional” (art. 1), "prórroga extraordinaria de los contratos de arrendamiento de vivienda habitual” (art. 2), "moratoria de deuda arrendaticia” (art. 3), "aplicación automática de la moratoria de la deuda arrendaticia en caso de grandes tenedores y empresas o entidades públicas de vivienda” (art. 4), "modificación excepcional y transitoria de las condiciones contractuales de arrendamiento en el caso de arrendadores no comprendidos entre los recogidos en el artículo 4 como consecuencia del impacto económico y social del COVID-19” (art. 8), “aprobación de una línea de avales para la cobertura por cuenta del Estado de la financiación a arrendatarios en situación de vulnerabilidad social y económica como consecuencia de la expansión del COVID-19" (art. 9).
}

34 Señala De La Vega García (2028, p. 1) que "La inversión en vivienda se ha encontrado en los últimos tiempos con el fenómeno de la eclosión de la inversión colectiva. Al respecto, el desarrollo de productos financieros cada vez más complejos ha permitido la diversificación del riesgo del inversor. En este sentido, gran parte de la inversión de los hogares se canaliza a través de formas colectivas (fondos) que permiten ajustar la misma a los objetivos de cada destinatario (de mayor a menor riesgo). Ya en 2003 se afirmaba respecto a la inversión colectiva que «su doble condición de fórmula de financiación desintermediada y de instrumento de ahorro privilegiado de los inversores minoristas la convierten en un sector de atención prioritaria para la política financiera española»... La aplicación de estas realidades al ámbito de la inversión inmobiliaria ha derivado en una generalización de instrumentos de inversión, entre los que destacan por su actualidad las «Sociedades Anónimas Cotizadas de Inversión Inmobiliaria» (SOCIMI) y el crowdfunding. 
jurídico debería desincentivar estas formas de inversión pues no es de recibo que la vivienda, lugar donde se materializa un derecho humano, sea objeto de especulación económica.

\section{El control de la renta en el contrato de arrendamiento de vivienda, un tema de ayer y de hoy.}

La preocupación por el arrendamiento de vivienda ha sido una constante en nuestro pasado jurídico, por ello una regulación que fije controles en la renta no supondrían ninguna novedad. Se puede constatar esta afirmación haciendo una referencia a las legislaciones ya derogadas que abordaban esta materia, aunque dada la naturaleza de este trabajo vamos a realizar un recorrido breve y parcial por los antecedentes para centrarnos en el momento actual, tomando como referencia la década de 1960. No obstante, merece ser recordado el RD de 22 de junio de 1920 en cuya regulación se incluyó un significativo control de la renta de los arrendamientos de vivienda ${ }^{35}$.

Partiendo de la década de los 60, el Decreto 4104/1964, de 24 de diciembre por el que se aprobó el ya derogado Texto refundido de la Ley de Arrendamientos Urbanos de 1964 (BOE n³12, de 29.12.1964) (en adelante LAU64), previó en sus arts. 94 y 95, un sistema de actualización de las rentas de aquellos contratos concertados con anterioridad a su entrada en vigor. Se trataba de solventar el problema existente de congelación de rentas. No obstante, para los contratos nuevos celebrados bajo su vigencia, el art. 97 de la LAU64 establecía que la renta será la estipulada por las partes que podrá ser objeto de aumento o reducción también por acuerdo. Nos recuerdan Díez Picazo y Gullón Ballesteros (1995, p. 401) que pese a ser un tema controvertido al principio, la LAU64 frente a la anterior legislación arrendaticia fue consolidando una vía de admisión de cláusulas de estabilización de las rentas que "aumentaban o disminuían según la variación de determinados índices, como el coste de vida e índices de precios al consumo”. No obstante como nos recordaban los autores citados "las cláusulas de pura elevación de renta han sido miradas con disfavor por la jurisprudencia. Las consideraba correctas si el incremento era moderado...En cambio, si eran elevadas y constantes, las declaraba nulas".

\footnotetext{
Aunque son instrumentos muy diferentes el inversor inmobiliario está interesado en ambos, tal y como lo muestra el auge de las mismas en el mercado actual. En este sentido, y a pesar de su retraso respecto a su pujanza hace ya algún tiempo en el mundo anglosajón, las SOCIMI han crecido espectacularmente en España en los últimos años, llegando a tener más de 12.000 millones de euros en activos y planeando su expansión a otros mercados financieros. El crowdfunding, por su parte, también es aplicado con éxito al ámbito del mercado inmobiliario, sobre todo a través de la modalidad de -crowdequity-“ .

35 A los efectos de mostrar cómo la renta es un tema sobre el que se ha legislado en el pasado, transcribimos
un precepto del RD de 22 de junio de 1920 , donde se aprecia intervención legislativa de la renta. Se trata del
art. 4 "Los contratos de inquilinato en las capitales de provincia y poblaciones de más de 20.000 almas, cuyo
alquiler no hubiese sido aumentado desde 31 de Diciembre de 1914 , o cuyo aumento se juzgue susceptible
de elevación, podrán ser revisados a instancia del propietario, según las normas que se establecen en la
siguiente escala: Los arriendos que no excediesen en 31 de Diciembre de 1914 de 1500 pesetas anuales, sólo
podrán elevar dicho precio en un 10 por 100. Desde 1.500 a 3.000 , sólo podrán elevarse en un 15 por 1000.
Desde 3.001 en adelante, en un 20 por 100. Estas normas podrán ser, sin embargo, alteradas en atención a
alguna de las circunstancias siguientes: a) Obras o mejoras que hayan sido hechas en las fincas y
principalmente aquellas que hayan contribuido a la higiene y salubridad de las viviendas. b) Relación
normal de los precios con el resultado de la investigación y comprobación de rentas practicadas por el
Registro Fiscal. c) Notable elevación en los precios de suministros especiales hechos por el arrendador".
} 
Para entender qué implicaba el régimen dibujado por la LAU64 es preciso conectarlo con el régimen de prórroga forzosa del contrato para el arrendador y potestativa para el arrendatario recogido en el derogado art. 57 y matizado por las causas de excepción a la prórroga y el sistema de subrogaciones inter vivos y mortis causa que prolongaba la permanencia del arrendatario y determinados familiares de éste en la vivienda arrendada. Esta situación provocó, como aclara la Exposición de Motivos del RDL 2/1985 de 30 de abril sobre medidas de Política Económica (BOE $\mathrm{n}^{\circ} 111$, de 09.05.1985) (en adelante, RDL 2/1985) que los alquileres iniciales que se pactaban en los nuevos contratos se fijaran "en unos altos niveles como consecuencia de que el propietario, al contratar, tiene presente la eventual indemnización que debe pagar al arrendatario para que acepte la rescisión del contrato”. Por ello en el art. 9 del RDL 2/1985 suprimió la prórroga forzosa para los contratos de arrendamiento que se celebrasen tras su entrada en vigor.

Nos aclara el Preámbulo de la LAU que "El Real Decreto-ley 2/1985 ha tenido resultados mixtos. Por un lado, ha permitido que la tendencia a la disminución en el porcentaje de viviendas alquiladas que se estaba produciendo a principios de la década de los ochenta se detuviera, aunque no ha podido revertir sustancialmente el signo de la tendencia. Por otro lado, sin embargo, ha generado una enorme inestabilidad en el mercado de viviendas en alquiler al dar lugar a un fenómeno de contratos de corta duración. Esto a su vez ha producido un movimiento de incremento de las rentas muy significativo, que se ha visto agravado por su simultaneidad en el tiempo con un período de elevación de los precios en el mercado inmobiliario". Y ello entre otras cuestiones provoca la necesidad de regular de nuevo la materia que vino de la mano de la LAU de 1994.

La LAU en un principio reguló en sus arts. 17 y ss la renta del arrendamiento de vivienda. En concreto el art. 17 establece que la renta es la libremente pactada por las partes y este es su contenido desde que la LAU entró en vigor pues ese precepto sólo ha sufrido una única reforma por la Ley $4 / 2013$ de 4 de junio, de medidas de flexibilización y fomento del alquiler de viviendas (BOE $n^{\circ} 134$, de 05.06. 2013) (en adelante, Ley 4/2013) ${ }^{36}$ que se limitó a introducir el apartado quinto donde se señalaba que el pago de la renta podía reemplazarse total o parcialmente por el compromiso del arrendatario de reformar o rehabilitar el inmueble en los términos y condiciones pactadas. Vemos por tanto que desde la vigencia de la actual LAU, la renta inicial ha sido dejada al acuerdo de las partes sin establecer ningún control o limitación al respecto ${ }^{37}$. No obstante, las actualizaciones sí que han sido objeto de sucesivas reformas, en concreto cinco, que se constatan en los distintos textos que ha tenido el art. 18.

\footnotetext{
${ }^{36}$ La reforma introducida por la Ley 4/2013, se señalaba en su Preámbulo que el objetivo fundamental de la misma era " flexibilizar el mercado del alquiler para lograr la necesaria dinamización del mismo, por medio de la búsqueda del necesario equilibrio entre las necesidades de vivienda en alquiler y las garantías que deben ofrecerse a los arrendadores para su puesta a disposición del mercado arrendaticio" actuando principalmente en el reforzamiento de "la libertad de pactos y dando prioridad a la voluntad de las partes, en el marco de lo establecido en el título II de la Ley” y en "La duración del arrendamiento, reduciéndose de cinco a tres años la prórroga obligatoria y de tres a uno la prórroga tácita, con objeto de dinamizar el mercado del alquiler y dotarlo de mayor flexibilidad. De esta forma, arrendadores y arrendatarios podrán adaptarse con mayor facilidad a eventuales cambios en sus circunstancias personales”. Sin embargo los hechos que sucedieron a esta norma pusieron de manifiesto que lejos de resolver problemas lo fomentaron y ello motivó sucesivos cambios legislativos.

${ }^{37}$ Resulta llamativo y en cierta forma incomprensible que otro precepto, el art. 9 de la LAU donde se regula el tiempo mínimo de duración del arrendamiento en beneficio del arrendado haya sido objeto de cinco modificaciones legales.
} 
Tras la publicación de la LAU, la actualización de la renta merecía una distinta configuración según nos encontrásemos en los primeros cinco años del contrato. De forma que si en los primeros cinco años la actualización operaría conforme al Índice General Nacional del Sistema de Índices de Precios de Consumo, sin embargo a partir de sexto año la actualización se regiría por lo pactado y en su defecto por el mismo sistema operado con anterioridad.

Tras la entrada en vigor de la Ley 4/2013, la renta pactada se podía actualizar por pacto expreso entre las partes y en defecto del mismo conforme al Índice General Nacional del Sistema de índices de precios de consumo. Obsérvese que la actualización convencional admitida fue objeto de críticas desde su publicación, pues la redacción dada por la reforma permitiría cualquier sistema de actualización incluso aquél que supusiese un incremento constante de la renta que haría inviable la posibilidad del arrendatario de prorrogar el contrato.

La siguiente reforma vino de la mano de la Ley 2/2015, de 30 de marzo, de desindexación de la economía española (BOE $n^{0} 77$, de 31.03.2015) (en adelante, Ley 2/2015), al establecer que la renta se actualizaría conforme a lo previsto en pacto expreso, pero en defecto de pacto "no se aplicaría revisión de renta a los contratos”. Además en caso de pacto expreso de actualización sin fijar un mecanismo de revisión, ésta se actualizaría conforme al Îndice de Garantía de Competitividad.

El Real Decreto-ley 21/2018, de 14 de diciembre, de medidas urgentes en materia de vivienda y alquiler (BOE $\mathrm{n}^{\circ}$ 304, de 18.12.2018) (en adelante, RDL 21/2018) vino a mantener la misma regulación establecida por la Ley $2 / 2015$, aunque añadió un párrafo de especial trascendencia pues limitaba las actualizaciones en caso de "renta reducida". En concreto señala el párrafo final añadido al art. 18.1: "En los contratos de arrendamiento de renta reducida, de hasta cinco años de duración, o de hasta siete años si el arrendador fuese persona jurídica, el incremento producido como consecuencia de la actualización anual de la renta no podrá exceder del resultado de aplicar la variación porcentual experimentada por el Índice de Precios al Consumo a fecha de cada revisión, tomando como mes de referencia para la revisión el que corresponda al último índice que estuviera publicado en la fecha de revisión del contrato. A estos efectos, se entenderá como "renta reducida" la que se encuentre por debajo de la establecida, para el conjunto del Estado y con carácter general, en el Real Decreto que regule el plan estatal de vivienda vigente a los efectos de tener habilitada la posibilidad de acogerse a algún programa de ayudas al alquiler". Esta significativa reforma tuvo escasa vigencia al quedar derogada por Resolución de 22 de enero de 2019, del Congreso de los Diputados, por la que se ordena la publicación del Acuerdo de derogación del Real Decreto-ley 21/2018, de 14 de diciembre, de medidas urgentes en materia de vivienda y alquiler (BOE $\mathrm{n}^{\circ} 21$, de 24.01.2019), que determinó la vuelta a la regulación fijada en la Ley 2/2015.

Finalmente, la actualización de la renta se rige por el Real Decreto-ley 7/2019, de 1 de marzo, de medidas urgentes en materia de vivienda y alquiler (BOE $n^{\circ} 55$, de 05.03.2019) (en adelante, RDL $7 / 2019$ ), donde se mantiene la regulación de la Ley $2 / 2015^{38}$ aunque se añade un párrafo de control: "En todo caso, el incremento producido como consecuencia de la actualización anual de la renta no podrá exceder del resultado de aplicar la variación porcentual experimentada por

\footnotetext{
38 Únicamente se introduce un cambio en la redacción pues se sustituye “revisión” por “actualización”.
} 
el Îndice de Precios al Consumo a fecha de cada actualización, tomando como mes de referencia para la actualización el que corresponda al último índice que estuviera publicado en la fecha de actualización del contrato".

Todas las reformas legislativas que han afectado a la LAU actualmente vigente contienen una disposición transitoria en virtud de la cual los contratos celebrados con anterioridad a la entrada en vigor de las mismas continuarán rigiéndose por lo establecido en el régimen jurídico que les era de aplicación. Ello determina una extraordinaria diversidad de regulaciones aplicables en los contratos actualmente vigente a los que posteriormente nos referiremos ${ }^{39}$.

El panorama legislativo queda incompleto si no se tiene presente que el actual contexto socioeconómico nacido del COVID, también ha planteado la necesidad de incidir en la renta del arrendamiento aunque de una forma excepcional, limitada temporalmente a consecuencia de los efectos socioeconómicos de la pandemia. Ello determinó la regulación contenida en el RDL 11/2020 donde como nos recuerda MAGRo SERVET (2020, p. 1) se incidió en las rentas en " el arrendamiento de viviendas fijando (art. 2) una prórroga extraordinaria de los contratos de arrendamiento de vivienda habitual (art. 3) una moratoria de deuda arrendaticia (art. 4) una aplicación automática de la moratoria de la deuda arrendaticia en caso de grandes tenedores y empresas o entidades públicas de vivienda (art. 5) una definición de la situación de vulnerabilidad económica a efectos de obtener moratorias o ayudas en relación con la renta arrendaticia de la vivienda habitual, etc. ${ }^{40}$.

La evolución normativa puesta de manifiesto, nos hace constatar que la regulación de la renta en los arrendamientos ha sufrido constantes modificaciones en lo que afecta a la actualización de la misma donde hemos transitado hacia un mayor control. No obstante, desde 1964 no se conocen límites o controles a la renta de partida lo que resulta muy llamativo pues el tiempo que también es un elemento principal del contrato de arrendamiento sí que ha sufrido numerosas reformas limitando la autonomía de las partes en favor del arrendatario. Resulta difícil comprender esta falta de control o limitación de la renta de partida cuando estamos ante un derecho humano, el derecho a la vivienda, que los poderes públicos deben promover.

En relación a las actuales circunstancias socioeconómicas que afectan a nuestra sociedad y aconsejan tomar medidas que incidan en renta de los contratos de arrendamiento de vivienda, es muy significativa la Sentencia del Tribunal Constitucional del Pleno 14/2020, de 28 de enero de 2020 (BOE núm. 52, de 29.02.2020) (en adelante, STC 14/2020). En dicha sentencia, se resolvió un recurso de inconstitucionalidad (número 2208-2019) en relación al RDL 7/2019. Entre los diversos motivos de inconstitucionalidad alegados en el recurso, nos interesa el que hace

\footnotetext{
39 Obsérvese que en todas las reformas salvo la producida por ley 2/2015, se incluye en la propia Disposición Transitoria el siguiente texto: "Sin perjuicio de ello, cuando las partes lo acuerden y no resulte contrario a las previsiones legales, los contratos preexistentes podrán adaptarse al régimen jurídico establecido en esta Ley".

40 En relación a los contratos de arrendamientos de vivienda, no cabría aplicar señaló MAGRO SERVET (2000, p. ) la cláusula rebus sic estantibus pues "Dado el destino de esta tipología de contratos respecto a vivienda... - morar de forma permanente- no se da el presupuesto jurídico habilitante para la invocación por el inquilino de la cláusula o regla rebus sic stantibus relativo a la alteración de la causa económica del contrato, pues no se alteran las circunstancias relativas al goce pacífico de la cosa arrendada, pudiendo destinarla el inquilino al uso pactado en idénticas circunstancias que en el momento en que se perfeccionó el contrato. No hay una afectación de la base del negocio jurídico por un paro o una declaración de ERTE”.
} 
referencia a "la ausencia de presupuesto habilitante" del citado RDL por no existir la extraordinaria y urgente necesidad requerida por el art. 86.1 $\mathrm{CE}^{41}$. Como fundamento de su pretensión los recurrentes citan en su recurso datos ${ }^{42}$ que contradicen a los señalados en la exposición de Motivos del RDL 7/2019 ${ }^{43}$. No obstante, la citada STC 14/2020 en el Fundamento

41 Como se señala textualmente en la STC 14/2020 los recurrentes alegan "tras hacer un resumen de la doctrina constitucional sobre el requisito de la «extraordinaria y urgente necesidad» (art. 86.1 CE)... que «la urgencia real no se puede identificar con la urgencia política electoralista, creada ad hoc por quien la invoca para justificar el uso del real decreto-ley, sino que debe ser una urgencia y una extraordinaria necesidad reales, que existan sobre la base de datos y circunstancias acreditadas, y a las que deba atender la acción del gobierno de manera excepcional por no existir un cauce de procedimiento legislativo de urgencia que permita abordar de manera eficaz esas situaciones que se han presentado y eran difíciles de prever».

42 En concreto según nos clarifica la STC 14/2020 en el recurso se “Expone a continuación una serie de datos oficiales tomados de Eurostat, del Ministerio de Fomento y del Consejo General del Poder Judicial, que contradicen la justificación ofrecida por el Gobierno, y al mismo tiempo niega que puedan tenerse en cuenta datos del Instituto Nacional de Estadística que el Ministro de Fomento reconoció haber conocido «ayer» en el debate de convalidación, celebrado un mes después de la aprobación del real decreto-ley. En este sentido, matiza que en España el 76,7 por 100 de viviendas se posee en régimen de propiedad y solo el 23,3 por 100 en régimen de alquiler, lo que arroja un total de «cerca de seis millones de viviendas en alquiler»; y que en el periodo 2006 a 2017 el mercado de alquiler cayó por efecto de la crisis económica un 17,3 por 100. Cuestiona por ello que la cita concreta de la situación del alquiler en solo seis provincias en la exposición de motivos (Madrid, Barcelona, Las Palmas, Baleares, Málaga y Santa Cruz de Tenerife) pueda servir de base para el real decreto-ley recurrido. Niega también eficacia al dato del 42 por 100 de hogares que destinan más del 40 por 100 de ingresos al pago del alquiler, presentada en la exposición de motivos, primero porque ese 42 por 100 lo es del 23,3 por 100 que posee vivienda en alquiler (es decir, solo un 9,7 por 100 del total de los hogares españoles), y luego porque desde 2014 hasta 2017, según Eurostat, esa «tasa de esfuerzo» se ha reducido en un 5,4 por 100, y la media en los últimos diez años es superior, del 43,4 por 100. La exposición de motivos tampoco explica de dónde toma el dato del crecimiento de los desahucios vinculados a contratos de alquiler «a un ritmo anual del 5 por 100». Los «datos reales», sin embargo, apuntan a un número de lanzamiento de arrendatarios «ínfimo», del 0,6 por 100 de todos los lanzamientos (36.340), según datos del Consejo General del Poder Judicial, es decir, 218 casos. Además, el porcentaje de población afectada por riesgo de perder la vivienda es del 2,8 por 100 de la población, muy inferior a la media europea de 5,2 por 100, según Eurostat. El recurso no quiere «minimizar» la importancia de esos desahucios para los afectados, pero argumenta que no puede erigirse en fundamento de una situación de «extraordinaria y urgente necesidad».

${ }^{43}$ En concreto se señala en la Exposición de Motivos del RDL 7/2019 que "es preciso subrayar que el requisito de extraordinaria necesidad y la urgencia de las medidas se apoyan y justifican en sólidos motivos. La grave situación de vulnerabilidad económica y social de un gran número de familias y hogares para afrontar los pagos de una vivienda en el mercado constituye el primer motivo de urgencia. Según datos de Eurostat, en el año 2017, más del 42\% de los hogares españoles destinaban más del 40\% de sus ingresos al pago del alquiler. Ello supone que España se sitúa 17 puntos porcentuales por encima del valor medio de la Unión Europea y, si no se adoptan las medidas oportunas, previsiblemente irá en aumento, ya que el precio de los alquileres se ha incrementado en los últimos tres años en más de un 15\% y, en algunas localizaciones, el incremento duplica el registrado en el conjunto de España. Este desigual y heterogéneo comportamiento del mercado del alquiler de vivienda pone de manifiesto la existencia de diversos factores que inciden en esta evolución, y que constituyen el segundo motivo que justifica la urgencia y extraordinaria necesidad de las medidas. Se observa que el incremento de los precios del mercado de la vivienda ha sido particularmente intenso en entornos territoriales de fuerte dinámica inmobiliaria caracterizados por una mayor actividad turística desarrollada sobre el parque de viviendas existente. Ello se pone de manifiesto si se analiza la evolución de los precios en los últimos años: las provincias en las que los precios de la vivienda se han incrementado con mayor intensidad han sido Madrid, Barcelona, Las Palmas, Baleares, Málaga y Santa Cruz de Tenerife. No cabe duda de que, aunque pueden existir diversos factores que explican este incremento de los precios, el fenómeno creciente del alquiler turístico de vivienda a través de plataformas p2p incide en un contexto en el que, además, la demanda de vivienda en alquiler está creciendo con intensidad. Si se analiza la evolución del alquiler en España de los últimos años, se observa que ha pasado de representar el 
Jurídico Cuarto afirma "los recurrentes no cuestionan la existencia de esta situación, sino su importancia, es decir, la decisión misma de actuar con urgencia mediante real decreto-ley. Pero ello representa una valoración esencialmente política de ordenación de prioridades de actuación que este Tribunal no puede enjuiciar. Frente a los porcentajes aportados por el Gobierno (más del 42 por 100 de hogares españoles destinan más del 40 por 100 de sus ingresos al pago del alquiler), los diputados recurrentes alegan que el porcentaje de vivienda en alquiler en España es reducido (solo el 23,3 por 100 del total de viviendas se posee en régimen de alquiler, frente al 76,7 de viviendas en régimen de propiedad) y que por tanto los hogares afectados son solamente el 42 por 100 de ese 23,3 por 100, es decir, aproximadamente el 9 por 100 del total; sostienen también que la «tasa de esfuerzo» en realidad se ha reducido en un 5,4 por 100 entre 2014 y 2017, desde que alcanzó su punto más alto (47,5 por 100) en el año 2014; y, finalmente, que ese sobreesfuerzo y la presión del alquiler turístico afecta solo o fundamentalmente a determinadas zonas de España. Pero ello no altera las características esenciales de la situación descrita; si acaso reduce el número de afectados, que sigue siendo numeroso y delimitado objetivamente, los localiza geográficamente y atenúa (moderadamente) su «tasa de esfuerzo»". Por tanto, se puede deducir que sea como sea la interpretación de los datos, estamos ante unas "circunstancias de extraordinaria y urgente necesidad”, y, esta especial situación todavía hace más necesario la regulación del control de la renta del arrendamiento de viviendas en la LAU. Obsérvese que a la fecha de realización de este trabajo, se ha anunciado por parte del Gobierno la futura regulación de la renta de los arrendamientos de vivienda, en una futura ley de vivienda.

\section{La regulación de la renta: un retrato actual}

La necesidad de controlar la renta en los contratos de arrendamiento de vivienda se ha planteado en numerosos ordenamientos de países de nuestro entorno, que han utilizado para ello variadas estrategias. Partiendo de los datos aportados por LÓPEZ-RODRÍGUEZ y DE LOS LLANOS MATEA (2020, pp.14-15), con un mero afán ejemplificador, se pueden destacar los siguientes. En relación a la limitación de la renta, algunas de las opciones para su abordaje son:

- Regulación de los precios pero sólo de terminadas viviendas (en Austria las antiguas)

- Establecer el control de la renta en ciertas zonas urbanas durante un periodo concreto (Francia, art. 140 de la Ley Elán de 2018)

- Fijación de un parámetro concreto de limitación de la renta del alquiler. (Luxemburgo)

- Establecimiento de una cláusula abierta de control. En Noruega aunque la renta se fija libremente sin embargo no puede ser irrazonable

Con respecto a la actualización de la renta, también se han adoptado soluciones diversas.

- Establecer periodos mínimos durante los cuales la renta no se puede actualizar (algunos estados de Australia)

- Prever que sólo cabe por acuerdo con los arrendatarios o por decisión judicial (Austria)

- Señalar que todo aumento debe ir precedido de un periodo mínimo de notificación (algunos estados de Australia)

régimen de tenencia del 20,3\% de la población en el año 2011, al 22,9\% en el año 2017, según los últimos datos de Eurostat, lo que supone un incremento del 12,8\% y puede representar alrededor de 700.000 viviendas más en alquiler en este periodo. Esta tendencia contrasta con la mayor estabilidad de la media de la Unión Europea, en la que el alquiler ha aumentado ligeramente del 29,6\% en 2011 al 30,0\% en 2017”. 
- Regular que cuando los inquilinos consideren excesivas las subidas, puedan solicitar la impugnación de las mismas (Estonia). En Polonia si el incremento supera el 3\% del valor de reemplazo los arrendatarios pueden impugnar dicho incremento

- En ciertas zonas tensionadas, los aumentos están limitados a un porcentaje en relación a la última cuantía de la renta pagada por el inquilino anterior, admitiéndose excepciones. (Francia)

- Establecer para determinadas zonas tensionadas límites concretos al aumento del alquiler durante un periodo temporal concreto (Irlanda )

Consideración especial merece la regulación de control de renta en Alemania que ha llevado a modificar varios parágrafos del BGB (Bürgerliches Gesetzbuch) destacando el art. 556.d.1 que señala que en las zonas con un mercado de vivienda tenso al comienzo de un arrendamiento, el alquiler no puede superar el promedio de alquiler en esa zona en más de un $10 \%$; y el parágrafo 556.d.2 que preceptúa que se autoriza a los denominados "Länder" a dictar ordenanzas que determinen esas zonas por un período de hasta cinco años. La aplicación de estos preceptos determinó la publicación de una Ordenanza en Berlín que declaró toda la ciudad de Berlín como zona de mercado tenso y ello provocó que el Tribunal Regional de Berlín plantease la inconstitucionalidad de los parágrafos 556.d.1 y 2 y a su vez que una propietaria interpusiera un recurso de inconstitucionalidad frente a los citados preceptos por violación del derecho a la igualdad, de la garantía de la propiedad privada y de la libertad general de acción. En la Resolución de 18 de julio de 2019, el Tribunal Constitucional Federal alemán (Bundesverfassungsgericht) consideró los citados parágrafos constitucionales al no contravenir el derecho de propiedad, libertad de contratación y principio de igualdad. Además el citado Tribunal realizó un pronunciamiento digno de mención "la garantía de la propiedad privada no protege las expectativas de los más altos ingresos por concepto de alquiler” ${ }^{44}$.

En cualquier caso, debe tenerse presente que el art. 556.d del BGB ha sido objeto de reforma ${ }^{45}$ estableciendo una ampliación como máximo hasta 2025, del plazo de vigencia de los reglamentos para determinar las "zonas de mercado tensas" que pueden elaborar los Länder.

Por otra parte, es preciso destacar que en el Land de Berlín se aprobó el 11 de febrero de 2020, la ley de limitación de renta en las vivienda en Berlín (Gesetz zur Mietenbegrenzung im Wohnungswesen in Berlin-MietenWoG bln), la denominada «Mietendeckel» que "a grandes rasgos ... establece, por un plazo de cinco años, que finaliza el 23 de febrero de 2025, la prohibición de que las rentas de alquiler pactadas hasta al 18 de junio de 2019 se puedan incrementar (§ 3) y que las rentas derivadas de contratos posteriores excedan de unos determinados límites ( $\$ 4)$, que fija para doce categorías de viviendas, según el año en el que se ocuparon por primera vez. De acuerdo con el § 6, dichos límites van desde 3,92 euros $\mathrm{m} 2$ para los que se ocuparon por primera vez antes de 1918 (sin calefacción colectiva ni baño) hasta 9,80 euros $\mathrm{m} 2$ para las viviendas que se ocuparon por primera vez entre 2003 y 2013 y tienen calefacción colectiva y baño... siguiendo con la normativa del Land de Berlín, podemos indicar que este ha aprobado el Reglamento de 19 de mayo de 2020, relativo al nivel autorizado del alquiler al inicio del arrendamiento de las viviendas

\footnotetext{
${ }^{44}$ Abstract of the German Federal Constitutional Court's Order of 18 of july 2019, 1 BvR 1595.

45 Nos referimos a la Ley de prórroga y mejora de las regulaciones del nivel autorizado del alquiler al inicio del arrendamiento, de 19 de marzo de 2020, que entró en vigor el 1 de abril de 2020 (Gesetz zur Verlängerung und verbesserung der Regelungen über die zulässige Miethohe bei Mietbeginn).
} 
de conformidad con el párrafo segundo del § 556d BGB (Verordnung zur zulässigen Miethöhe bei Mietbeginngemäß § 556d Absatz 02 de diciembre Bürgerliches Gesetzbuch Mietenbegrenzungsverordnung-), en el que considera esta ciudad estado como «zona de mercado tenso», con vigencia desde el 1 de junio de 2020 hasta el 31 de mayo de 2025 " ${ }^{46}$.

Observamos cómo los países de nuestro entorno han regulado medidas de control o limitación de la renta, que en nuestro ordenamiento solo ha sido seguida por la Ley 11/2020 CAT. En la LAU aunque existen algunas normas que limitan la renta éstas son manifiestamente insuficientes especialmente por no afectar a la renta de partida. Además debe tenerse presente que todas las medidas señaladas en la LAU deben ser aplicadas en los términos señalado en su art. 4.2 donde se establece que los arrendamientos de viviendas cuya superficie sea superior a 300 metros cuadrados o en los que la renta inicial en cómputo anual exceda de 5,5 veces el salario mínimo interprofesional en cómputo anual y el arrendamiento corresponda a la totalidad de la vivienda, se regirán por la voluntad de las partes, en su defecto por lo dispuesto en el Título II de la presente ley y de forma supletoria por las disposiciones del Código Civil.

En cualquier caso, se hace preciso profundizar sobre el panorama actual que afecta a la renta para determinar sus insuficiencias, debilidades y en su caso fortalezas. Para ello, necesariamente se debe distinguir entre aquellos controles de la renta que se aplican a los nuevos contratos y los controles que afectan a las actualizaciones. Serían los controles de primera y segunda generación siguiendo la terminología apuntada por ARNOTT (1995, pp. 101 y 102).

\subsection{Controles de la renta de primera generación: la renta de partida}

La vigente LAU, como ya hemos señalado, no limita la renta de partida del arrendamiento. Así se deduce del art. 17.1 cuando preceptúa que "La renta será la que libremente estipulen las partes". Esta libertad de estipulación deja al arrendatario indefenso frente a rentas excesivas cuando tiene interés de celebrar un contrato, $y$, también favorece que los contratos de arrendamiento no se prorroguen al finalizar el plazo legal, ante la expectativa del arrendador de poder concertar otro contrato con renta manifiestamente superior. En fin la falta de límite de la renta puede afectar al acceso al arrendamiento y a la permanencia en el mismo.

No obstante, merecen ser analizados dos supuestos que se relacionan con la renta. El primero le afecta directamente pues regula la posibilidad de que el pago de la renta se reemplace por el compromiso del arrendatario de reformar o rehabilitar el inmueble. El segundo aunque se refiere a los gastos generales y servicios individuales que puede asumir el arrendatario, se relaciona con la renta en tanto que va a suponer una contraprestación que debe satisfacer el arrendatario y le puede hacer más gravoso el contrato.

La LAU, en el art. 17. 5 LAU ${ }^{47}$ regula una opción que fue introducida tras la reforma por Ley 4/2013. El citado precepto hace posible que las partes acuerden libremente "que, durante un plazo

\footnotetext{
46 Vid. Dictámen 7/2020, de 5 d'agost, sobre la Proposició de llei de mesures urgents en matèria de contenció de rendes en els contractes d'arrendament d'habitatge, pp. 9 y 10.

47 De La EnCARnación ValCARCel (2019) menciona que la masovería urbana que se asemeja a renta /rehabilitación. Además nos recuerda NASARRE AzNAR (2015, p. 216) que "aunque esta posibilidad podía acordarse por las partes antes de la reforma, este contrato no era considerado como «arrendamiento
} 
determinado, la obligación del pago de la renta pueda reemplazarse total o parcialmente por el compromiso del arrendatario de reformar o rehabilitar el inmueble en los términos y condiciones pactadas". Si bien esta norma ofrece una acertada flexibilidad para abonar la renta, sin embargo puede ser perjudicial si se entiende que el precepto introduce un mero período de carencia durante el cual el arrendatario no debe pagar la renta. GARCíA Teruel (2019, pp. 487-486) considera que es "un auténtico arrendamiento ad meliorandum, en que la obligación principal del arrendatario es llevar a cabo unas determinadas obras... Así, el art. 17.5 LAU constituye una novedad en cuanto al precio del arrendamiento urbano, que ya no requiere ser en dinero". Pero esta interpretación, puede ser muy gravosa para el arrendatario pues hace que la renta sea incierta. Por ello, parece más adecuado entender que el art. 17.5 al ser una manifestación de la renta, precisa que se asigne al pago en especie por rehabilitación o reforma un equivalente en dinero (Molina Roig (2018, p. 209) pues de esta forma la opción permitida en el art. 17.5 supondría una significativa ventaja para acceder a una vivienda arrendada.

También se relaciona con la renta, el tema de los gastos generales y servicios individuales que pueden corresponden satisfacer al arrendatario al provocar que el acceso a la vivienda arrendada sea más costoso. Aunque la localización sistemática del art. 20 de la LAU que regula estos gastos en el Capítulo III “De la renta”, del Título II de la LAU permitiera interpretar que los citados gastos deberían integrase en la misma, sin embargo es otra la posición que se debe adoptar. Coincidimos con Verdera SERVER (2007) en que "Dado que el art. 20 LAU menciona la posibilidad de que los gastos generales y de servicios generales, tributos, cargas y responsabilidades sean asumidos por el arrendatario, cabe pensar que esos conceptos, en tanto se exijan separadamente, no constituyen renta (aunque sí «cantidades cuyo pago haya asumido o corresponda al arrendatario» «ex» art. 27.2.a) LAU).... Nada impide, sin embargo, que las partes acuerden un aumento de la renta teniendo en cuenta el importe prorrateado y aproximado de esas cantidades para simplificar de ese modo sus relaciones". A mayor abundamiento también favorece la citada interpretación, la propia denominación del art. 20 que no menciona el término "renta" que sin embargo forma parte de la denominación de los otros preceptos que integran en Capítulo III (vid. arts. 17, 18 y 19). En cualquier caso, aunque los gastos generales o de servicios individuales no sean renta, sin embargo incide en ella pues suponen un incremento real de la definitiva contraprestación que tiene que abonar el arrendatario.

El art. 20 de la LAU distingue entre "los gastos por servicios con que cuente la finca arrendada que se individualicen mediante aparatos contadores serán en todo caso de cuenta del arrendatario" y los gastos generales que "las partes podrán pactar... para el adecuado sostenimiento del inmueble, sus servicios, tributos, cargas y responsabilidades que no sean susceptibles de individualización y que correspondan a la vivienda arrendada o a sus accesorios, sean a cargo del arrendatario". Este pacto precisa para su validez que conste por escrito y esté determinado su importe anual a la fecha del contrato.

En este ámbito, debe recordarse que existe una significativa jurisprudencia de las Audiencias Provinciales sobre los gastos generales que puede asumir el arrendatario, destacando aquella que atribuye un carácter constitutivo al pacto sobre los mismos. Ello supone una protección del

urbano», es decir, estos acuerdos no estaban protegidos por la LAU (periodo de duración mínima del contrato de arrendamiento, parámetros tasados en cuanto a la actualización de la renta, derecho legal de adquisición preferente, etc.)”. 
arrendatario en especial en relación a poder determinar el límite a los incrementos anuales señalado en el art. 20.2 LAU ${ }^{48}$. Sólo conociendo el importe anual de los gastos cabe fijar el límite. Mantiene esta doctrina la SAP Audiencia Provincial de Málaga (Sección $7^{a}$, Melilla) de 25 enero de 2018 (Sentencia 8/18, MP: Mariano SANTOS PeÑAlVER) y la SAP de Cantabria (Sección $1^{\text {aa }}$ ) de 14 de abril de 2003. (Sentencia n. 182/03, MP: Javier DE LA HOZ DE LA ESCALERA) ${ }^{49}$. En cualquier caso, el límite a los incrementos señalados en la norma del "doble de aquél en que pueda incrementarse la renta”, no parece justificada y supone admitir un incremento excesivo de la contraprestación que haya de abonar el arrendatario.

Parece razonable que según la LAU los "gastos por servicios" sean abonados por el arrendatario dado que provienen de su propio consumo, pero se valora como una debilidad que la norma permita pactos por los que el arrendatario asuma gastos generales de la vivienda. Estos pactos dan entrada a un efectivo aumento de la contraprestación que definitivamente debe abonar el arrendatario que se verá de hecho obligado a suscribirlo para acceder al contrato. Observemos que incluso el propio precepto valora quien es el deudor de dichos gastos generales cuando señala "el pacto que se refiera a tributos no afectará a la Administración” y ello mismo podría predicarse de los otros gastos generales (cuotas de comunidad...) que sólo se podrían solicitar al propietario.

Los arts. 17 y 20 de la LAU nos alertan de la existencia de debilidades: no existe un límite a la renta de partida y además la efectiva contraprestación que tiene que abonar el arrendatario puede verse incrementada con el abono por éste de los gastos generales. El sistema dibujado en la LAU carente de control en la renta de partida es por tanto notoriamente insuficiente y sorprende si se compara con las respuestas dadas por las legislaciones de nuestro entorno, a demandas sociales de la vivienda similares a las nuestras. Se hace necesario acometer una reforma cuyos primeros pasos se han dado de la mano de la Disposición Adicional Segunda del RDL 7/2019, que crea el Sistema Estatal de Índices de Referencia del precio del alquiler de vivienda, que si bien no tiene un carácter vinculante, tiene por objetivo "garantizar la transparencia y el conocimiento de la evolución del mercado del alquiler de viviendas, así como para aplicar políticas públicas que incrementen la oferta de vivienda asequible y para facilitar la aplicación de medidas de política fiscal". Esta disposición que fue objeto de recurso de inconstitucionalidad, desestimado por STC 14/2020, establecía un plazo de ocho meses para su elaboración, que justificadamente se ha demorado hasta junio de 2020 dado el contexto socioeconómico derivado de la pandemia.

\footnotetext{
48 Señala el art. 20.2 LAU que "durante los cinco primeros años de vigencia del contrato, o durante los siete primeros años si el arrendador fuese persona jurídica, la suma que el arrendatario haya de abonar por el concepto a que se refiere el apartado anterior, con excepción de los tributos, sólo podrá incrementarse, por acuerdo de las partes, anualmente, y nunca en un porcentaje superior al doble de aquel en que pueda incrementarse la renta conforme a lo dispuesto en el apartado 1 del artículo 18".

49 Cfr. con la SAP de Vizcaya (Sección 5ª) de 6 de marzo de 2013 (sentencia 82/2013, MP: María Elisabeth HUERTA SÁNCHEZ) y SAP de Asturias (Sección $4^{\text {a }}$ ) de 24 de noviembre de 1999 (sentencia n. 708/99, MP: José Ignacio Álvarez Sánchez), entre otras, donde se declara respectivamente la exigencia del arrendatario de abonar un gasto general pese a no haber sido pactado o no haber sido fijado su importe, en atención a que dichos gastos ya habían sido satisfechos por el arrendatario con anterioridad. En estas sentencias pese a su fallo, no se desvirtúa la naturaleza constitutiva del pacto acordando el abono de los gastos generales, pues se falla conforme al expediente de la buena fe en el sentido de que nadie puede ir en contra de sus propios actos que.
} 
En el apartado b) de la citada Disposición Adicional Segunda, para determinar el índice estatal propone tomar los datos que constan en la "Agencia Estatal de la Administración Tributaria, en el Catastro Inmobiliario, en el Registro de la Propiedad, en los registros administrativos de depósitos de fianza y en otras fuentes de información, que sean representativos del mercado del alquiler de vivienda". Aunque la introducción de las citadas referencias es positiva en tanto que pueden ayudar a configurar la realidad, sin embargo merece algunas consideraciones. Por una parte, los registros administrativos de fianza no operan en todas las comunidades autónomas y por ello ese dato aunque relevante no tiene una aplicación general. Por otra parte, la mención a "otras fuentes de información" debería evitar en todo caso la utilización de datos procedentes de portales inmobiliarios dado que éstos pueden ser inadecuados pues a veces suman a los precios las comisiones de los intermediarios y otras veces no son más que una invitación a contratar que puede luego no materializarse en el contrato. En cualquier caso, resulta significativo resaltar que la Disposición señala que las comunidades autónomas "podrán definir de manera específica y adaptada a su territorio, su propio índice de referencia” y esta posibilidad parece acertada, pues las Comunidades Autónomas son las que de forma más adecuada pueden determinar cada índice dado el específico conocimiento de la zona.

La publicación del Sistema Estatal de Îndices de Referencia accesible a través de la página correspondiente del Ministerio de Transportes, Movilidad y Agencia Urbana ${ }^{50}$, supone un gran avance para una futura regulación estatal de la renta. Crea un ámbito de transparencia del mercado del alquiler que es requisito imprescindible para una futura regulación ${ }^{51}$.

\subsection{Sobre la actualización de la renta.}

El panorama actual en relación a la actualización de la renta de los contratos de arrendamiento de vivienda, es complejo. La razón de ello es que el art. 18 LAU donde se regula, ha sido objeto de sucesivas reformas que nunca han tenido una eficacia retroactiva. Ello provoca que actualmente estén vigentes contratos de arrendamientos a los que se les aplica diferentes sistemas legales de actualización de la renta. Es una debilidad del sistema la inexistencia de medidas con aplicación generalizada.

Los contratos de renta antigua que todavía están vigentes y encuentran su causa en contrato anterior a 9 de mayo de 1985, sólo son susceptibles de ser actualizados conforme al IPC, según señala la Disposición Transitoria Segunda de la LAU.

Los contratos perfeccionados desde la entrada en vigor de la LAU hasta el 06 de junio de 2013, el alquiler que se había actualizado conforme a IPC los cinco primeros años y a partir del sexto año se actualiza por acuerdo entre las partes y en su defecto por el IPC.

Los contratos firmados durante la vigencia de la Ley 4/2013 se pueden actualizar por el sistema pactado o en defecto por el IPC, sin que norma que limite el posible acuerdo al que hayan llegado las partes.

\footnotetext{
${ }^{50}$ https://www.mitma.gob.es/vivienda/alquiler/indice-alquiler.

51 Vid. la STC 14/2020 en el Fundamento de Derecho V donde se señala que “... el abogado del Estado sostiene que el conocimiento del funcionamiento del mercado del alquiler y su transparencia es requisito imprescindible para su adecuado funcionamiento...”.
} 
Los contratos acogidos a la Ley 2/2015 la actualización de la renta solo opera si existe pacto expreso entre las partes, pues en otro caso no opera la actualización. No obstante, si en el contrato se acuerda su actualización pero nada se prevé sobre cómo se realizará el precio del alquiler se actualizará cada año, aplicando el Índice de Garantía de Competitividad. El pacto que conste en el contrato no encuentra ningún límite.

Los contratos regulados por el RDL 21/2018, mantienen el mismo régimen que en la Ley 2/2015 aunque estableciendo un control respecto de las denominadas "rentas reducidas" a las que ya nos hemos referido.

Finalmente debemos referirnos a aquellos contratos que se rigen por RDL $7 / 2019$ donde se establece que las rentas no están sujetas a actualización anual salvo pacto expreso entre las partes, aunque debe tenerse presente que será frecuente que la actualización se pacte y se incluya en el contrato. En cualquier caso si existe cláusula de actualización, tras la reforma ésta tendrá como como límite la variación del IPC. Además debe tenerse presente que en el caso en el que las partes no hayan determinado el índice a aplicar, la renta se actualizará cada anualidad según el último mes publicado del Índice de Garantía de Competitividad en la fecha de cada actualización, pero en ningún caso podrá exceder la variación del IPC. Observamos que a partir de 2019 existe un control claro y definido a las actualizaciones a fin de favorecer la estabilidad y asequibilidad.

El panorama expuesto, constata que en la actualidad existen contratos cuya actualización está sometida a normas diferentes, e incluso están vigentes contratos que se actualizan según lo pactado sin ningún límite.

Aunque no sea una actualización, en tanto que supone un aumento de la renta a abonar, también debe ser mencionado el art. 19 de la LAU que permite la subida de la renta por mejoras siempre que hayan transcurrido cinco o siete años de duración del contrato (según sea el arrendador persona física o jurídica). En este caso la LAU no es tímida al acoger un límite concreto para la subida del veinte por ciento, techo que consta desde la publicación de la LAU y que se ha mantenido en las sucesivas reformas de la norma ${ }^{52}$.

Hemos observado de lo expuesto, que la LAU dibuja un panorama en el que existe control en las actualizaciones de la renta, sin embargo carece por completo de control de la renta de partida de

\footnotetext{
52 El art. 19 de la LAU ha sido reformado por la Ley 4/2013, RDL 21/2018, RDL 7/2019. Las modificaciones de estas normas se han centrado en adaptar la norma al cambio de plazo obligatoria que iban fijando en los arrendamientos. No obstante, debe tenerse presente que con el RDL 21/2018 se introdujo un párrafo $4^{\circ}$ que se han mantenido en el actual RDL 7/2019 donde textualmente se señala: "Sin perjuicio de lo dispuesto en los apartados anteriores y de la indemnización que proceda en virtud del artículo 22, en cualquier momento desde el inicio de la vigencia del contrato de arrendamiento y previo acuerdo entre arrendador y arrendatario, podrán realizarse obras de mejora en la vivienda arrendada e incrementarse la renta del contrato, sin que ello implique la interrupción del periodo de prórroga obligatoria establecido en el artículo 9 o de prórroga tácita a que se refiere el artículo 10 de la presente Ley, o un nuevo inicio del cómputo de tales plazos. En todo caso, el alcance de las obras de mejora deberá ir más allá del cumplimiento del deber de conservación por parte del arrendador al que se refiere el artículo 21 de esta Ley”. En este caso el arrendatario en virtud del art. 22 podría tener derecho, si se dieran los presupuestos, a una reducción de la renta y una indemnización.
} 
los contratos de arrendamiento. En contraste con ello, merece ser destacada, la contención de la renta regulada en Cataluña.

\subsection{La Ley del Parlament de Catalunya de medidas urgentes en materia de contención de rentas en los contratos de arrendamiento de vivienda}

Con la publicación y entrada en vigor de la LEY 11/2020 CAT ${ }^{53}$, el Parlament de Catalunya ha dado un paso muy significativo en la materia objeto de estudio, pues ha incorporado en su ordenamiento medidas de contención de rentas para los contratos de arrendamiento de viviendas. No obstante, las medidas de contención reguladas no van a tener una aplicación generalizada y definitiva. Como señala la propia Exposición de Motivos, la imposición de las restricciones señalas en la citada ley precisan "calificar determinadas zonas del territorio como áreas de mercado tensa” pero ello se realiza con un carácter excepcional pues está limitado a un plazo de duración máximo de cinco años. No tiene una duración indefinida como ocurre en Francia. Además las citadas medidas de contención no afectan de forma generalizada a todos los contratos de arrendamiento pues junto a las causas de exclusión de aplicación de la ley señaladas en su art. 1.2, se debe tener presente que ésta norma no se aplica a los contratos de arrendamiento de vivienda ubicados en zonas con mercado de vivienda tenso que hayan sido concluidos antes de entrar en vigor la ley (disposición transitoria primera). Si a ello añadimos que en la disposición final cuarta, se retrasa la entrada en vigor de la norma en tres años en el caso de viviendas de nueva edificación o viviendas resultantes de un proceso de rehabilitación, podemos constatar que la norma deja fuera de su ámbito de aplicación una parte significativa de contratos de arrendamientos.

En cualquier caso, no puede dejar de resaltarse que la Ley 11/2020 CAT tiene gran relevancia pues supone adoptar, al fin, medidas de contención que inciden en la renta inicial de los contratos de arrendamiento de vivienda aunque puede quedar excluidas respecto a viviendas que tengan una superficie útil superior a ciento cincuenta metros ${ }^{54}$. A mayor abundamiento, no puede obviarse que si bien la norma tiene un carácter limitado sin embargo tiene un horizonte mucho más ambicioso pues como se estipula en su disposición final primera "el gobierno debe aprobar en el plazo de nueve meses un proyecto de ley de regulación los contratos de arrendamiento de bienes" ${ }^{55}$.

53 Con anterioridad, había sido publicada una norma sobre esta misma materia. Nos referimos al Decreto Ley $9 / 2019$, de 21 de mayo, de medidas urgentes de contención de rentas en los contratos de arrendamiento de vivienda, que sin embargo no fue validado por el Parlamento catalán. El Acuerdo de derogación fue publicado en el DOGC n' 7911, de 05.07.2019.

54 Vid. la Disposición Adicional Segunda de la L 11/2020 CAT.

55 Debe tenerse presente como señala la Exposición de Motivos de la Ley 11/2020 CAT que "Atendiendo a la complejidad de la materia y a la distinta urgencia con que deben abordarse los contenidos, esta regulación se hará efectiva en dos fases: en primer lugar, la ley regula un régimen excepcional de contención de rentas de alquiler aplicable en zonas de mercado de vivienda tenso; más adelante, en un plazo que la disposición final primera fija en nueve meses, el Gobierno debe presentar al Parlamento un proyecto de ley de regulación integral de los contratos de arrendamiento de bienes, como parte integrante del libro sexto del Código Civil, relativo a las obligaciones y los contratos”. La preocupación del legislador catalán por la 
Merece destacarse que las normas de contención de la renta se centran exclusivamente en la renta inicial. La Ley 11/2020 CAT no incluye ninguna especialidad en relación a los controles de segunda generación dado que según prevé su art. 8 las actualizaciones se regularán conforme a la normativa reguladora de los contratos de arrendamiento de vivienda.

En relación a la contención de la renta inicial del contrato, la Ley 11/2020 CAT tras un esclarecedor retrato de la situación social en su Exposición de Motivos ${ }^{56}$, señala en su primer artículo que ésta tiene por objetivo la contención y moderación de la renta en los contratos de arrendamiento de vivienda. Para ello como primer paso en los arts. 2 a 4 se fija los requisitos, procedimiento y contenido de la declaración de áreas con mercado tenso del alquiler. Seguidamente el art. 5 preceptúa que la declaración de zona de mercado tensa requiere que sea de aplicación en esa área el índice de referencia de precios del alquiler y es precisamente aquí donde apreciamos una debilidad en esta ley.

Para la declaración de zona de mercado tensa, según el art. 2 de la Ley 11/2020 CAT se deben tener presente el cumplimiento de cualquiera de las condiciones señaladas en la norma que ponen el acento en la situación que de riesgo para el acceso de un arrendatario a un contrato de arrendamiento de vivienda ${ }^{57}$. Una vez declarada una zona, como área de mercado tensa, se le aplicará al citado territorio un índice de referencia de precios de alquiler de vivienda que toma

asequibilidad de los arrendamientos también se ha puesto de manifiesto respecto de los arrendamientos de locales de negocio. Así en el Decreto Ley 34/2020, de 20 de octubre, de medidas urgentes de apoyo a la actividad económica desarrollada en locales de negocio arrendados (DOGC núm. 8252, de 22 .10.2020), en su art. 2 regula la reducción de la renta a falta de acuerdo.

56 Señala expresamente la Exposición de Motivos de la Ley 11/2020 CAT: "La salida de la crisis financiera internacional y la progresiva reactivación económica de los últimos años han incidido con fuerza en el mercado de la vivienda, que ha experimentado cierta retracción del acceso en régimen de propiedad, por razones no solo de precio sino también de financiación, y un aumento sustancial de la demanda de vivienda de alquiler. Este aumento, combinado con la poca duración de los contratos de arrendamiento en aplicación de la legislación del Estado, ha propiciado una fuerte escalada de los precios, que en Cataluña han crecido en torno a un treinta por ciento en los últimos cinco años. Esta tendencia ha sido aún más acusada en el caso de Barcelona y su entorno metropolitano, al añadirse a la misma el auge del turismo urbano, que ha desviado viviendas hacia usos no residenciales, así como la entrada de capital internacional en grandes operaciones de inversión inmobiliaria. La fuerte subida de los precios ha causado dificultades económicas muy graves para el acceso a la vivienda y para permanecer en ella. Una situación agravada aún más por la pandemia de Covid-19, que ha provocado una crisis sanitaria sin precedentes y, en consecuencia, una nueva crisis económica y social...”.

57 Señala la Ley 11/2020 CAT en su “Artículo 2. Requisitos para la declaración de áreas con mercado de vivienda tenso. Son áreas con mercado de vivienda tenso los municipios o partes de municipio que están especialmente en riesgo de no disponer de la suficiente dotación de viviendas de alquiler a un precio asequible que permita acceder a las mismas a toda la población. Esta situación de riesgo puede venir determinada por el cumplimiento de cualquiera de las siguientes condiciones: a) Que la media del precio de los alquileres de vivienda experimente en dicha área un crecimiento sostenido claramente superior al de la media del territorio de Cataluña. b) Que la carga del coste del alquiler de la vivienda en el presupuesto personal o familiar supere de media en dicha área el treinta por ciento de los ingresos habituales de los hogares, o que la media del precio de los alquileres de vivienda supere el treinta por ciento de la renta media de las personas menores de treinta y cinco años. c) Que el precio de los alquileres de vivienda haya experimentado, en los cinco años anteriores al momento de la declaración, un crecimiento interanual acumulado de al menos tres puntos porcentuales por encima de la tasa interanual del índice de precios al consumo de Cataluña”. 
únicamente como referencia el "precio de mercado", lo que puede evitar conseguir una efectiva contención de la renta.

Efectivamente, en los contratos de arrendamiento a los que sea aplicable la Ley 11/2020 CAT, según el art. 6.1 la renta inicial no puede sobrepasar ${ }^{58}$ " el precio de referencia para el alquiler de una vivienda de características análogas en el mismo entorno urbano", ni "la renta consignada en el último contrato de arrendamiento, actualizada en cualquier caso de acuerdo con el índice de garantía de competitividad, aplicado de forma acumulada en el período transcurrido entre la fecha de celebración del anterior contrato de arrendamiento y la fecha de celebración del nuevo contrato, si la vivienda afectada se ha arrendado en los cinco años anteriores a la entrada en vigor de la presente ley". Vemos como el "precio de mercado" que ha provocado que la zona sea declarada de mercado tensa, se utiliza como parámetro de la contención. Así se desprende por razones notorias del presupuesto que afecta a la "renta consignada en el último contrato de arrendamiento", y, también de la forma en la que se calcula el "precio de referencia”. Señala el art. 7 de la Ley 11/2020 CAT que el precio de referencia se determina conforme a los datos que constan en el Registro de fianzas de alquiler de fincas urbanas ${ }^{59}$.

Si es trascendente la declaración de zona de mercado tensa del alquiler, tanto más lo es la fijación del índice de referencia de precios, pues este índice será el que determinará la efectiva contención de la renta. Por ello, la formación de este "índice de referencia de precios" conforme al precio de mercado puede ocasionar efectos no deseados para conseguir una efectiva contención de la renta al permitir perpetuar precios elevados en los contratos de arrendamientos.

Por otro lado, merece destacarse que la ley 11/2020 CAT, en los apartados 3 y 4 del art. 6, acoge una especialidad en la regulación atendiendo a la situación económica de las partes del contrato y que permite una subida de la renta en una norma dictada para contenerla. Establece la ley, que para el caso de un contrato de nuevo arrendamiento sujeto al régimen de contención de la renta que tenga por objeto una vivienda que haya sido arrendada dentro de los cinco años anteriores a la entrada en vigor de la ley, si la parte arrendadora es "una persona física cuya unidad de convivencia tiene unos ingresos iguales o inferiores a 2,5 veces el indicador de renta de suficiencia de Cataluña, incluidas las rentas de los arrendamientos”, el único índice de referencia será el previsto en la renta consignada en el último contrato de arrendamiento, actualizada en cualquier caso de acuerdo con el índice de garantía de competitividad, "entendiendo que, si la renta consignada en el último contrato de arrendamiento es inferior al precio de referencia correspondiente, la nueva renta podrá incrementarse hasta el citado precio de referencia". Aunque esta norma, no se aplica si los ingresos del arrendatario son iguales o inferiores a 3,5 veces el indicador de renta de suficiencia de Cataluña, supone una forma de favorecer la aplicación del "precio de referencia” que ha sido fijado en atención al precio de mercado.

\footnotetext{
58 Se debe tener presente las excepciones señaladas en los apartados 2,3 y 4 del art. 6 de la Ley 11/2020.

${ }^{59}$ Señala el art. 7.1 de la Ley 11/2020 CAT que "El precio de referencia para los contratos de arrendamiento de vivienda sujetos al régimen de contención de precios regulado por la presente ley se establece a partir del índice de referencia de precios de alquiler de viviendas que determina y hace público el departamento competente en materia de vivienda, a partir de los datos que constan en el Registro de fianzas de alquiler de fincas urbanas y de las características adicionales que se tienen en cuenta para calcular dicho índice en cada momento. A efectos de la presente ley, se considera como precio de referencia el índice mencionado, sin tener en cuenta los márgenes de precio superior e inferior".
} 
En cualquier caso, el arrendador puede proponer que la renta se incremente en relación al precio de referencia si se han producido obras de rehabilitación en los términos previstos en el art. 7, y, en el caso de que se hayan realizado obras de mejora una vez transcurrido el plazo mínimo legal (art. 11). En ambos casos, se permite un incremento de la renta sin atenerse a los límites del art. 6 , que es especialmente significativo en relación a las obras de mejoras pues se contrapone al límite señalado para ellas en el art. 19 de la LAU. También resulta un punto débil de la norma que se admita el acuerdo de incremento o disminución de la renta con una variación máxima del $5 \%$ si existen o no características específicas en la vivienda ${ }^{60}$ pues dadas las características que se mencionan en la norma, será habitual que se produzca el incremento.

Relacionada con la renta que debe satisfacer el arrendatario se encuentra el tema de la asunción por éste de los gastos generales y servicios individuales. El art. 9 de la Ley 11/2020 CAT permite a las partes pactar que los arrendatarios asuman dichos gastos de conformidad a la LAU, lo que implicaría que de forma efectiva el esfuerzo económico a realizar por el arrendatario se vería significativamente incrementado. Es cierto que la asunción de los citados gastos depende del acuerdo de las partes, pero en última instancia puede dejar abierto un espacio abierto que favorezca un aumento significativo del precio a satisfacer por el arrendatario para acceder al arrendamiento. Obsérvese que este art. 9 ha sido objeto de modificación por el Decreto Ley 50/2020, de 9 de diciembre, de medidas urgentes para estimular la promoción de vivienda con protección oficial y de nuevas modalidades de alojamiento en régimen de alquiler (DOGC n.8292, de 11.12.2020) que ha añadido un tercer párrafo con el siguiente contenido: "En los contratos de arrendamiento de viviendas que habían estado arrendadas dentro de los cinco años anteriores a la entrada en vigor de esta ley, es nulo el pacto que obliga la parte arrendataria a asumir los gastos generales y de servicios individuales que no habían sido previstos en el contrato de arrendamiento anterior”.

Destaca la regulación contenida para el caso de incumplimiento de la norma. Desde el punto de vita civil el art. 12 otorga el derecho de arrendatario a solicitar el reembolso o "la restitución de las cantidades abonadas en exceso, con devengo del interés legal del dinero, incrementado en tres puntos". Nos encontramos ante una pena civil, pues el incremento en tres puntos determina una sanción que se ve obligado a abonar el arrendador y que además no es la única pues la Ley señala otras sanciones de naturaleza administrativa. La norma que nos ocupa también prevé sanciones para el caso de su incumplimiento remitiéndose a estos efectos a la Ley 18/2007, de 28 de diciembre, del derecho a la vivienda (DOGC núm. 5044 de 09.01.2008, BOE nº. 50, de 27.02.2008).

La regulación contenida en la legislación catalana, aunque presenta algunas debilidades merece sin embargo una consideración positiva en tanto que supone un compromiso decidido del legislador de afrontar el control de la renta de partida de los contratos. El tiempo determinará su efectiva incidencia sobre la protección del derecho a la vivienda de los ciudadanos pero mientras tanto supone un intento claro de favorecer su protección y empezar ya a aplicar medidas que son acordes con las adoptadas en otros ordenamientos.

En cualquier caso, no se pueden obviar al abordar esta Ley 11/2020 CAT dos temas que le afectan y que son objeto de opiniones encontradas. Nos referimos a dos cuestiones: competencia

${ }^{60}$ Vid. los apartados 3, 4, y 5 del art. 7 de la Ley 11/2020 CAT. 
legislativa para dictarla, y posible vulneración con esta norma del principio libertad de pactos acogida en el art. 17 de la LAU (la renta inicial será la acordada por las partes). Dado que la cuestión competencial se presta a un análisis complejo que escapa al contenido de este trabajo a pesar de su evidente trascendencia ${ }^{61}$, vamos a referirnos únicamente la contradicción existente entre el sistema de contención de la renta (Ley 11/2020 CAT) y la libertad de pacto en la renta (art. 17 LAU).

Coincidimos con PONCE (2020, p. 1) cuando afirma que "Si el reconocimiento de la libertad de pactos es deducida como un principio general del sistema, heredero de la tradición liberal decimonónica del laisser faire, laisser passer, también debería serlo el que la misma sea susceptible de limitaciones legales, en el marco de un Estado Social y Democrático de Derecho, como el español, que reconoce la existencia de desigualdades entre personas y colectivos a corregir por los poderes públicos (art. 9.2 CE), reconoce la función social de la propiedad que permite su delimitación legal (art. $33 \mathrm{CE}$ ) así como la necesidad de respetar, proteger y hacer eficaz el derecho a la vivienda, ligado a la dignidad de las personas, así como a sus derechos a la intimidad o a la integridad física, como recuerda nuestra jurisprudencia, en el marco del servicio de interés general de la vivienda (art. 4 de la Ley del Derecho a la Vivienda de Cataluña). Los límites de la ley no eliminarían la libertad de pactos dado que, por ejemplo, se puede seguir eligiendo contratar o no y también decidir con quien se contrata (eso sí, sin discriminación, prohibida por la Ley del Derecho a la Vivienda de Cataluña de 2007, arts. 45 y ss.)”. ${ }^{62}$

Reincidiendo en lo anterior, la libertad de pactos como expresión del principio de autonomía de la voluntad no es ilimitada y debe respetar como nos recuerda el art. 1255 del Código civil la ley, la moral y el orden público. El principio de autonomía de la voluntad no se ve perjudicado cuando se limita el pacto que recaiga sobre la renta, dado que existe una obligación de los poderes públicos de promover las condiciones necesarias para garantizar que los ciudadanos tengan derecho a disfrutar de una vivienda digna y adecuada. Además el derecho a la vivienda es un derecho humano que exige que los poderes públicos eviten contratos que puedan perjudicarlo. La libertad de pactos no puede favorecer una regulación que determine precios de arrendamiento

\footnotetext{
61 Sobre el tema de la competencia para publicar esta ley, vid. el Dictamen 7/2020, de 5 d'agost, sobre la Proposició de llei de mesures urgents en matèria de contenció de rendes en els contractes d'arrendament d'habitatge, emitido por el Consell de Garanties Estatutàries de Catalunya y la propia Disposición Final Tercera de la ley 11/2020 CAT que señala cual es el marco competencial de la norma que se dicta "al amparo del artículo 129 del Estatuto de autonomía de Cataluña, por el que se atribuye a la Generalidad de Cataluña la competencia exclusiva en materia de derecho civil, salvo en las materias que el artículo 149.1.8 de la Constitución atribuye al Estado, y del artículo 137 del Estatuto de autonomía, por el que se atribuye a la Generalidad la competencia exclusiva en materia de vivienda.”

62 Relaciona PoncE (2000, p. 1) este tema con la Sentencia del Tribunal Supremo de los Estados Unidos Sentencia Lochner vs. New York (1905) dictada en relación a “Una ley de New York de 1895 prohibía que los trabajadores de panaderías hicieran jornadas de más de diez horas diarias o de más de sesenta horas semanales. Joseph Lochner, propietario de una panadería fue sancionado por haber hecho laborar a uno de sus empleados más del tiempo permitido. Impugnó la multa, pero perdió en los tribunales del Estado y acudió a la Suprema Corte. En la sentencia Lochner vs. New York (1905) la Suprema Corte anuló la ley estatal de regulación de los horarios de trabajo por ser contraria a la libertad de contratación y a la propiedad". Vid.http://lecturasconstitucionaleseua.juridicas.unam.mx/sentencias-tseu/lochner-vs-new-york1905/\#: :text=New\%20York\%20(1905),198\%20US\%2045\&text=Joseph\%20Lochner\%2C\%20propietario\%20de\%20una,acudió\%20a\%20la\%20Supr ema\%20Corte.
} 
de vivienda excesivamente elevados que impidan el acceso efectivo a la vivienda a sectores de la población.

Siendo lícita una regulación que prevea la contención de las rentas de las zonas declaradas de mercado tenso, otra cuestión será si las concretas medidas son las idóneas para conseguirlo y sólo la puesta en marcha de las mismas podrán responder a dicho interrogante.

\section{Hacia una futura regulación del control de la renta en la LAU}

El Derecho civil es el derecho de la persona tanto en su faceta estrictamente personal como en la patrimonial, siempre identificado por un contenido permanente que debe necesariamente gravitar sobre el respeto y la promoción de los derechos humanos.

El derecho humano a una vivienda digna, adecuada y asequible, convierte en necesidad la exigencia de que exista una clara regulación civil que incorpore normas que protejan a los arrendatarios de rentas excesivas, evitando así los "desahucios" por impago de estas rentas e impidiendo los "desahucios invisibles" que llevan a numerosos ciudadanos a desistir de sus arrendamientos por no poder contratar o prorrogar los contratos ni asumir las actualizaciones de las rentas.

Aunque en Cataluña se ha abordado legislativamente la contención de la renta tras la publicación de la Ley 11/2020 CAT, sin embargo se hace preciso incorporar en el ordenamiento una regulación generalizada de los controles de la renta. Es cierto que en la actualidad, existe una vocación política en este sentido, pero es necesario que ésta definitivamente se materialice en la correspondiente reforma de la LAU.

Los efectos conseguidos en aquellas legislaciones que ya han adoptado medidas en el ámbito del control de la renta aunque deben ser tenidos en cuenta para afrontar una futura regulación, sin embargo no tendrían que ser determinantes pues toda medida que pretenda proteger el "derecho a la vivienda" deberá necesariamente adaptarse al contexto socioeconómico del lugar en el que se ejercite. Muestra de ello, es que las distintas normas vigentes sobre la materia distinguen y especifican la concreta localización de su ámbito de aplicación.

El Tribunal Europeo de Derechos Humanos (en adelante, TEDH) ha dictado sentencias relevantes en relación al control de la renta que pueden señalar el marco a una futura regulación. Especialmente significativa es la STEDH (Sección 3ª), de 10 de enero de 2017, Caso Meciar y Otros contra Eslovaquia ${ }^{63}$ y en concreto su apartado $24^{64}$. Del mismo se puede concluir que aunque las medidas de control de la renta suponen una injerencia del Estado sobre el derecho de propiedad, sin embargo cabe admitirlas siempre que se parta de los presupuestos señalados en el artículo 1

\footnotetext{
${ }^{63}$ Se señala en el apartado 7 de la sentencia que "La situación de los demandantes es estructuralmente y contextualmente idéntica a la situación presentada en Bittó y otros contra Eslovaquia (28 de enero de 2014) (fondo del asunto) y 7 de julio de 2015 (satisfacción equitativa) y en tres casos posteriores relativos al régimen de arrendamiento protegido en Eslovaquia (Krahulec contra Eslovaquia,.. Bukovčanová y otros contra Eslovaquia ... y Rudolfer contra Eslovaquia ... adoptadas el 5 de julio de 2016)”.

64 En el citado apartado 24, la sentencia citada en texto, reitera la misma doctrina fijada en la ST EDH (Sección $3^{\text {a }}$ ), de 28 de enero de 2014, Caso Bitto y Otros contra Eslovaquia.
} 
del Protocolo de la CEDH, es decir, que la injerencia esté "prevista por la ley", "persiga un objetivo legítimo de política social” y cumpla con el requisito de "interés general”.

A mayor abundamiento, el TEDH también ha tenido en cuenta al valorar la legalidad de medidas de control de la renta el "equilibrio justo necesario entre los intereses generales de la comunidad y la protección del derecho de propiedad de los demandantes”, es decir que exista "proporcionalidad". A este respecto resulta llamativo que en las sentencias dictadas por el TEDH los demandantes y gobierno en defensa de sus posiciones encontradas utilicen como único argumento para fundamentar la existencia o no de "proporcionalidad", la relación entre el importe de la renta controlada y la renta de mercado, cuando la renta de mercado puede ser excesiva en relación a las rentas medias de las familias. Es discutible, por ello, el uso del "precio de mercado" como parámetro para valorar la "proporcionalidad", pues precisamente es el "mercado sin límites" el que obstaculiza el acceso a la vivienda y determina las medidas legislativas de control. Debe tenerse en cuenta que el TEDH también da información sobre otro parámetro que podrían ayudar a determinar la proporcionalidad cual es "evaluar los efectos reales del control de alquileres sobre la capacidad del demandante para mantener su propiedad" ${ }^{65}$. En cualquier caso, en la valoración de la proporcionalidad, se observa un defecto dado que tan solo se analiza la proporcionalidad desde la perspectiva del propietario y no desde los "intereses generales de la comunidad" que debe garantizar el acceso a una vivienda digna y adecuada, que afectando a la función social de la propiedad, forma parte de su propio contenido esencial.

De la doctrina expuesta del TEDH, se puede deducir que una futura norma que controle la renta no supondrá una injerencia en el derecho de propiedad siempre que persiga un objetivo legítimo de política social y cumpla con el requisito del interés general y sea "proporcional".

La doctrina del Tribunal Constitucional, también nos da pautas para garantizar la no vulneración del derecho de propiedad por una normativa que limite o controle la renta. En concreto, la Sentencia del Tribunal Constitucional del Pleno de 17 de marzo de 1994 (BOE n. 89, de 14.04.1994) resolviendo una cuestión de inconstitucionalidad sobre varios artículos de la LAU64 y en relación al ya derogado art. 57 que regulaba la prórroga forzosa, fija como parámetros para determinar la constitucionalidad en caso de intervención legislativa en la propiedad, que ésta "no suponga por sí misma la pérdida de la utilidad económica de los arrendamientos concertados ni per se el origen de una pérdida esencial, o vaciamiento, de la utilidad económica del bien arrendado". Por ello serían factibles medidas de contención de la renta que implicasen una limitación para favorecer el derecho a la vivienda, siempre que no impliquen vaciar la utilidad económica del bien arrendado.

Pero es preciso afrontar el tema que nos ocupa desde otra perspectiva que nos conduce a relacionar estrechamente las medidas legislativas de control de la renta con la defensa de los derechos humanos y la consecución del derecho acogido en el art. 47 CE. En este sentido, debe tenerse presente necesariamente la Resolución 21.01.2021 sobre el acceso a una vivienda digna y asequible para todos. En la citada Resolución el Parlamento Europeo pide a la Comisión que

65 Vid. apartado 38 de la Sentencia del Tribunal Europeo de Derechos Humanos (Sección $3^{\text {a }}$ ), de 5 de julio de 2016., Caso Bukovcanova y Otros. contra Eslovaquia; apartado 33 de la Sentencia del Tribunal Europeo de Derechos Humanos (Sección 3 ${ }^{\text {a) }}$, de 5 de julio de 2016, y, apartado 38 de la Sentencia Tribunal Europeo de Derechos Humanos (Sección $3^{\text {a }}$ ), de 5 de julio de 2016, Caso Rudolfer contra Eslovaquia. 
desarrolle urgentemente "una estrategia integrada a escala de la Unión de vivienda social, pública, no segregada y asequible... para crear un marco que propicie que se garantice una vivienda de calidad para todos que sea segura, saludable, accesible y asequible". También se pide a los Estados miembros que apliquen las recomendaciones específicas por país en materia de asequibilidad de la vivienda y que los planes nacionales de vivienda asequible se incluyan en los programas nacionales de reforma.

Todo lo expuesto hasta el momento pone de manifiesto la necesidad perentoria de regular controles a la renta de los arrendamientos de vivienda, regulación que deberá tener presente determinados parámetros para favorecer el efectivo acceso a una vivienda digna y asequible. Seguidamente se proponen alguno de los parámetros que podrían inspirar una futura regulación de la renta de los contratos de arrendamientos de vivienda:

1.- Dado que la futura regulación se justifica en motivos de interés social, es preciso determinar el ámbito subjetivo y objetivo de aplicación de la norma, pues sólo en los casos en los que el "interés social” lo requiera deberá aplicarse la norma. En este sentido, parece aconsejable seguir las indicaciones de otras normas ya dictadas en las que se distingue entre arrendadores que sean "grandes tenedores" (personas jurídicas o personas físicas con un número elevado de viviendas en arrendamiento) ${ }^{66} \mathrm{y}$ el resto de los “arrendadores individuales”. También deberían tener una especial consideración los arrendatarios especialmente vulnerables. Además desde un punto de vista objetivo, sería conveniente mantener al margen de las reglas de control de renta siguiendo la línea acogida en la LAU, aquellos contratos de arrendamiento cuya superficie sea superior a 300 metros cuadrados o en los que la renta inicial en cómputo anual exceda con creces del salario mínimo interprofesional en cómputo anual, siempre que dicho arrendamiento se corresponda a la totalidad de la vivienda. En estas viviendas no estaría justificada la restricción a la autonomía de la voluntad para promover del derecho a una vivienda digna y asequible.

2.- En relación a los controles de primera generación (renta de partida), el control de la renta debe operar especialmente en aquellas zonas donde se estén pagando rentas excesivas en relación de la renta media de las familias que impidan el acceso a la vivienda de sectores significativos de la población. Por ello, con carácter previo se hace preciso clarificar la zona en la que hay que intervenir que denominaremos "área con mercado de vivienda tenso", siguiendo la terminología usada en la Ley 11/2020 CAT. En este sentido es significativo que la Resolución 21.01.2021 subraye "la necesidad de desarrollar una definición exhaustiva de asequibilidad de la vivienda a escala de la Unión" y entre los indicadores a tener en cuenta resalte "las tasas de desahucio y pobreza" y la necesidad de determinar el "umbral de referencia para la tasa de sobrecoste de la vivienda que supone una carga excesiva en función de las rentas medias de las familias”. Entre otros posibles, éstos índices nos podrán clarificar cuándo un área debe ser declarada de mercado tensa.

\footnotetext{
66 En el mismo sentido vid. el art. 1 del Real Decreto-ley 35/2020, de 22 de diciembre, de medidas urgentes de apoyo al sector turístico, la hostelería y el comercio y en materia tributaria (BOE n.334, de 23.12.2020). El citado precepto que regula medidas extraordinarias dirigidas a arrendamientos de locales de negocio, es aplicable cuando la parte arrendadora "sea una empresa o entidad pública, o un gran tenedor, entendiendo por tal la persona física o jurídica que sea titular de más de 10 inmuebles urbanos, excluyendo garajes y trasteros, o una superficie construida de más de $1.500 \mathrm{~m} 2$ ”.
} 
Un vez determinada que una zona es "área de mercado tensa", seguidamente debe precisarse un "índice de referencia de rentas" como se hace en la Ley 11/2021 CAT. Dicho índice podría determinarse, a falta de concreción por las CCAA, con base al índice del precio de las viviendas publicado por el Ministerio de Transportes, Movilidad y Agenda Urbana. Puede ser muy operativo para proceder a esta declaración seguir los criterios fijados en el RDL 7/2019 y así sería preciso utilizar datos provenientes de la Agencia Tributaria, Registro de la Propiedad, registros administrativos de depósitos de fianza ${ }^{67}$, en tanto no se generaliza la obligación de depositar en organismos administrativos las fianzas y se establece un sistema de control de los depósitos. No parece aconsejable utilizar la referencia a "otra forma de información" que pudieran ser extraídas de los portales inmobiliarios pues en ellos se recogen invitaciones a contratar que no se tienen que corresponder con el precio definitivo del contrato que se esté abonando.

Dado que este "índice de referencia de rentas" es calculado en relación al "precio de mercado", debería ajustarse para conseguir una adecuada contención de la renta a un determinado porcentaje del mismo que podría ser señalado por las CCAA o en su defecto por el Estado. Para precisar este porcentaje, sería preciso tener presente la Recomendación 21.01.2021 donde se señala que "una vivienda es asequible si el presupuesto restante de su inquilino es cuando menos suficiente para atender otros gastos fundamentales para una vida digna”.

Declarada una zona como "área de mercado de vivienda tensa" y determinado el "índice de referencia de rentas", no se deben sobrepasar ninguno de los siguientes parámetros al fijar la renta:

- El precio del alquiler actualizado que estaba fijado en el contrato de arrendamiento anterior suscrito en los cinco o siete años anteriores, si ha existido. Se sigue un criterio semejante al fijado en la LEY 11/2020 CAT (art. 7.3) y el plazo fijado se corresponde con el plazo legal recogido en la LAU

- Un porcentaje concreto del "Índice de referencia de la renta” fijado por el Estado o Comunidad Autónoma para dicha zona de mercado tensa. El porcentaje podría ser fijado cada año en los presupuestos generales del Estado o de las Comunidades Autónomas atendiendo a la relación entre el importe que señale el índice de referencia y la renta media de las familias según el instituto Nacional de Estadística. Con la fijación de este porcentaje se trata de solventar el inconveniente que puede plantear que el índice de referencia se extraiga de datos de un mercado que ha sido declarado tensionado.

El tope fijado a la renta, debería ser flexibilizado atendiendo a las siguientes cuestiones:

- La posibilidad a salvo de pacto en contrario, de repercutir el precio de obras de mejora finalizado el plazo de prórroga legal siempre que no suponga un incremento de la renta del $20 \%$. Se sigue la previsión contenida en el art.19. Sin embargo no cabría la posibilidad de elevar las rentas por mejora durante la vigencia del plazo legal del arrendamiento.

- Los “arrendadores individuales”, podrán incrementar en un porcentaje la renta siempre que existan servicios o características en la vivienda arrendada que supongan efectivos

67 Con este fin es necesario que en todas las CCAA exista obligación de depositar la fianza y que se intensifiquen los controles para su depósito legal. 
beneficios al arrendatario en relación a viviendas similares de la zona. En este punto, sería aconsejable subrayar que los servicios o características fueran manifiestamente especiales.

- Los gastos generales de la vivienda cuyo pago corresponda al arrendador (IBI, comunidad de propietarios...) no podrán ser repercutidos en el inquilino. Se debe evitar así que se produzca un incremento de la cantidad efectiva a abonar al margen de la renta.

- Para el caso de que los arrendadores devengan vulnerables durante el plazo legal del contrato, si el arrendador es "gran tenedor" la renta quedará congelada sin que quepa actualización.

- Se hace preciso adoptar un sistema de determinación de la renta especial en los casos de rehabilitación, a fin de dar cumplimiento a la solicitud de la Resolución 21.01.2021 que insta a los estados miembros y otras autoridades que fomenten la rehabilitación de viviendas abandonadas frente a la construcción de nuevas viviendas.

En cualquier caso, es importante que el definitivo tope que sirva de base al contrato de arrendamiento celebrado, se recoja expresamente en el contrato.

Pero el control de la renta sería insuficiente si no se atendiera a la posibilidad de que existan arrendatarios que estén soportando rentas manifiestamente excesivas aunque no se encuentren en "área de mercado de vivienda tensa”. Por ello, inspirándonos en la regulación de otros países como es el caso de Noruega o Nueva Zelanda ${ }^{68}$, se plantea la introducción de una regla que permita acudir a los tribunales para solicitar la reducción o rebaja de la renta, en los casos que se esté soportando un precio del alquiler excesivamente oneroso en relación a arrendamientos similares o en atención a excepcionales circunstancias socioeconómicas.

3.- En relación a los controles de segunda generación (actualizaciones)

Aunque el sistema de actualización previsto en el art. 18 LAU parece razonable, es aconsejable dictar una disposición transitoria estableciendo una retroactividad en grado mínimo de modo que la normativa actualmente vigente se aplique a todos los contratos ya celebrados y cuya eficacia esté aun desplegándose. En cualquier caso, la regulación de esta materia debe descartar cualquier diseño que implique únicamente la continua elevación de la renta.

4.- Una futura norma no debería prescindir de una concreta intervención en los contratos de arrendamientos actualmente vigentes que supongan una renta excesiva para los arrendatarios, pues normas retroactivas de esta naturaleza no son extrañas a nuestro ordenamiento como se pone de manifiesto en la propia LAU en sus disposiciones transitorias que regulaban situaciones nacidas al amparo de la legislación anterior.

En fin, con la propuesta realizada se pretende favorecer la reflexión sobre aquellas medidas de contención de la renta que en general se deberían incorporar al ordenamiento, para hacer efectivo el derecho de los ciudadanos a una vivienda digna, adecuada y asequible. La necesidad de la reforma es clara pues el legislador debe evitar que la vivienda sea un bien sometido a las reglas del mercado cuando es eje de un derecho humano. Es el momento de legislar. 


\section{Bibliografía}

Richard ARNOTT (1995), “Time for revisionionism on Rent Control?”, Journal of Economic Perspectives, vol. 9, nº 1, 1995, pp. 99-12.

Beate Gsell, Markus Artz, Arroyo Amayuelas, (2017), "La protección del arrendatario de vivienda en el derecho privado Alemán y Español: dos modelos antagónicos”, Revista Electrónica de Direito, Outubro 2017, n.3.

Domingo BeLlo JANEIRO (1994)), "La función social de la propiedad y la ley de arrendamientos urbanos (A propósito de la Sentencia del Tribunal Constitucional de 17 de marzo de 1994", Revista Dereito, vol. III, núm.1, 1994.

Marta BlANCA CARRASCo (2014), La reforma de los arrendamientos urbanos efectuada por la Ley 4/2013, edit. Reus, Madrid.

Francisco CABRILLA RodRíguEZ (2019), “Arrendamientos urbanos: la vieja historia se repite”, El Notario del S.XXI, $\mathrm{n}^{\circ}$ 86, pp. 1-4.

Ana María De La ENCARNACIÓN VALCARCEl (2019) "Urbanismo emergente y nuevas formas de vivienda colaborativa: ¿es posible otro futuro urbano", Revista General de Derecho Administrativo número 52.

Francisco De La VeGa GaRCía (2018), "El inversor ante dos opciones de mercado inmobiliario" Revista de Derecho Bancario y Bursátil num. 152/2018, BIB 2018\13065.

Luís Díez-Picazo y Antonio Gullón Ballesteros (1995), Sistema de Derecho civil. Vol. II, El contrato en general. La relación obligatoria. Contratos en especial. Enriquecimiento sin causa. Responsabilidad extracontractual, $7^{\text {a }}$ edic., edit. Tecnos, Madrid.

Rosa María GARCÍA TeRUEL (2019), La sustitución de la renta por la rehabilitación o reforma de la vivienda en los arrendamientos urbanos, Tirant lo Blanch.

Marx Gigling, Estudio comparado de la regulación del alquiler en Berlín y París 2017-2018, Observatori Metropolità de l'Habitage de Barcelona, Redacción Max GigLING- Equipo Observatori Metropolità de L'Habitage.

Mathias LeHMANN, "Las medidas legislativas alemanas relacionadas con la crisis del covid-19 en el ámbito del derecho civil”, Revista de Derecho Civil, vol. VII, núm. 2, especial (mayo 2020), pp. 3-7.

David LÓPEZ-RodRíGUEZ y María De Los Llanos Matea (2020), "La intervención pública en el mercado del alquiler de vivienda: una revisión de la experiencia internacional”, Documento ocasional no 2002, Banco de España. Eurosistema. 
Vicente MAGRo SERVET (2020), “A vueltas con el impago de rentas en locales de negocio. Alcance del Real Decreto-Ley 15/2020, de 21 de abril, de medidas urgentes complementarias para apoyar la economía y el empleo", Diario La Ley, No 9627, Sección Doctrina, 7 de Mayo de 2020, pp. 1-18.

Vanessa GarCía HeRrera (2016), "Personas con discapacidad y derecho a una vivienda digna y adecuada”, Revista Aranzadi Unión Europea núm 8/2016.

Elga Molina RoIG

-(2018), Una nueva regulación para los arrendamientos de vivienda en un contexto europeo, Tirant Lo Blanch, Valencia.

- (2019), "Una reforma de la legislación sobre arrendamiento de vivienda según el derecho comparado europeo", Revista jurídica de consumidores y usuarios, Nbr. Desahucios y arrendamientos, mayo 2019, pp. 1 a 27

\section{Sergio NASARRE AZNAR}

- (2015)," La eficacia de la Ley 4/2013, de reforma de los arrendamientos urbanos, para aumentar la vivienda en alquiler en un contexto europeo", Revista Crítica de Derecho Inmobiliario $\mathrm{n}^{\mathrm{o}} 747$, pp. 205-245.

- (2017), "Cuestionando algunos mitos del acceso a la vivienda en España, en perspectiva europea “, Cuadernos de Relaciones Laborales, vol.35, n 1, pp. 43 a 69.

- (2020), Los años de crisis de la vivienda. De las hipotecas subprime a la vivienda colaborativa. Edit. Tirant Lo Blanch

Gregorio PeCes-BARba MARTínez (1999), "El futuro de los derechos humanos”, Crítica, año 58, no 957, pp. 16 a 19.

Juli PONCE (2020), ¿¿Es constitucional la ley catalana que limita el precio de los alquileres? (I)”, Hay Derecho, https://hayderecho.expansion.com/2020/10/04/es-constitucional-la-leycatalana-que-limita-el-precio-de-los-alquileres-i/

Francisca RAMÓN FERNÁNDEZ (2017), “La función social de la vivienda y la protección de los consumidores”, Revista de Derecho Patrimonial núm. 44/2017, pp. 1-21.

José Manuel RodRíguez RAmos (2015), "La defensa del derecho a la vivienda desde la Universidad: laboratorio jurídico sobre desahucios de la Universidad de Córdoba”, Estudios jurídicos sobre vivienda y desahucios. Análisis jurídico y propuestas alternativas, coord. Francisco Javier ARELLANO GómEZ, Manuel Jesús DíAz GómEZ, Sevilla, pp. 196-206.

Cristina VALLEJo Ros y Jesús SÁNCHEZ GaRCÍA (2018), “Cree necesario una modificación de la LAU que amplíe el plazo mínimo legal del contrato de arrendamiento de uso de vivienda, así como fijar un precio tasado del arrendamiento?”, Revista de Derecho Vlex, N.167, abril 2018, pp. 1 a 19.

Rafael Verdera SERVER (2007), “Determinación de la renta” en Arrendamientos urbanos. Comentarios, Jurisprudencia y Formularios, dir. Francisco de Paula BLASCO GASCó, Tomo I, Tirant lo Blanch. Valencia, TOL1.066.691 